\title{
Modification of Hardwood Derived Biochar to Improve Phosphorus Adsorption
}

\author{
Laura Arbelaez Breton ${ }^{1}$, Zainab Mahdi ${ }^{1}$, Chris Pratt ${ }^{2,3}$ and Ali El Hanandeh ${ }^{1, *(D)}$ \\ 1 School of Engineering and Built Environment, Griffith University, Nathan, QLD 4111, Australia; \\ lauambiental@gmail.com (L.A.B.); z.mahdi@griffith.edu.au (Z.M.) \\ 2 School of Environment and Science, Griffith University, Nathan, QLD 4111, Australia; c.pratt@griffith.edu.au \\ 3 Australian Rivers Institute, Griffith University, Nathan, QLD 4111, Australia \\ * Correspondence: a.elhanandeh@griffith.edu.au
}

Citation: Arbelaez Breton, L.; Mahdi, Z.; Pratt, C.; El Hanandeh, A. Modification of Hardwood Derived Biochar to Improve Phosphorus Adsorption. Environments 2021, 8, 41 . https://doi.org/10.3390/ environments8050041

Academic Editors: Nelson Belzile and Wen-tien Tsai

Received: 10 February 2021

Accepted: 2 May 2021

Published: 6 May 2021

Publisher's Note: MDPI stays neutral with regard to jurisdictional claims in published maps and institutional affiliations.

Copyright: (c) 2021 by the authors. Licensee MDPI, Basel, Switzerland. This article is an open access article distributed under the terms and conditions of the Creative Commons Attribution (CC BY) license (https:/ / creativecommons.org/licenses/by/ $4.0 /)$.

\begin{abstract}
The excessive application of phosphorus in agricultural lands leads to serious environmental issues. Efficient application is beneficial from an economic and environmental perspectives. Biochar can be used as a carrier for slow release of phosphate. However, its adsorption capacity is limited. In this work, biochar was prepared at different pyrolysis temperatures $\left(350-550{ }^{\circ} \mathrm{C}\right)$. The biochar prepared at $550{ }^{\circ} \mathrm{C}$ had the highest adsorption capacity and was selected for modification by magnesium impregnation. Magnesium modification enhanced the adsorption capacity by $34 \%$ to a theoretical max adsorption capacity of $463.5 \mathrm{mg} \cdot \mathrm{g}^{-1}$. The adsorbed phosphate can be desorbed. The desorption was bi-phasic with fast- and slow-release fractions. The distribution of the phosphate fractions was $\mathrm{pH}$ dependent with slow release being most prominent in neutral conditions. $\mathrm{Mg}$ modified biochar can be used to recover phosphate and then used as a carrier for slow release of phosphate. The bi-phasic desorption behaviour is useful as the fast release fraction can provide the immediate phosphate needed during plant establishment, while the slow-release fraction maintains steady supply over extended periods.
\end{abstract}

Keywords: phosphorus recovery; adsorption; biochar; modification; Mg modified biochar

\section{Introduction}

Phosphate is an essential and irreplaceable nutrient required for plants development and growth. However, it has become a matter of major concern due to the rapid depletion of phosphorus reserves, the increasing demand for fertiliser in the agricultural sector and the negative environmental impacts it has in water bodies (eutrophication) [1-3]. Therefore, in terms of coping with the increasing demand for fertiliser and minimising the environmental impact caused by phosphate runoff, different approaches should be employed to ensure effective delivery of the phosphate as needed.

Biochar is an organic porous material, resulting from the thermochemical conversion or thermal decomposition of biomass in a limited oxygen environment. It is a solid and carbonrich material which can be used as an adsorbent agent because of its physicochemical properties such as high surface area and cation exchange capacity [4]. Wu and Wei [5] presented several benefits of biochar, among them it helps to improve fertility in soils, contributes to reduce nutrient leaching - a major cause for eutrophication in water bodiesand improves crop production. Other soil and environmental benefits of biochar are shown in Figure 1. Because of all its potential uses and benefits, biochar has received much attention as it is perceived as an environmentally sound and low-cost material with promising applications in agricultural and environmental fields [4,6,7]. When placed in the soil, biochar can hold carbon for thousands of years as well as retaining nutrients for the plant; this makes it more stable and effective than other organic matters used as fertilisers, such as compost and manure [8]. In addition, biochar has also been shown to enhance soil physical properties such as porosity, water holding capacity and soil aggregate 
stability $[9,10]$. Therefore, biochar has potential as a soil amendment contributing to long term soil fertility for plants under drought conditions. However, most studies are focused on enhancing biochar phosphate adsorption and less attention has been given to phosphate desorption processes [2,11]. Understanding not only the adsorption of phosphate by biochar but also how this recovered phosphate can be effectively released (desorption) will improve phosphate management in soils as well as its bioavailability for plants and crops in the future.

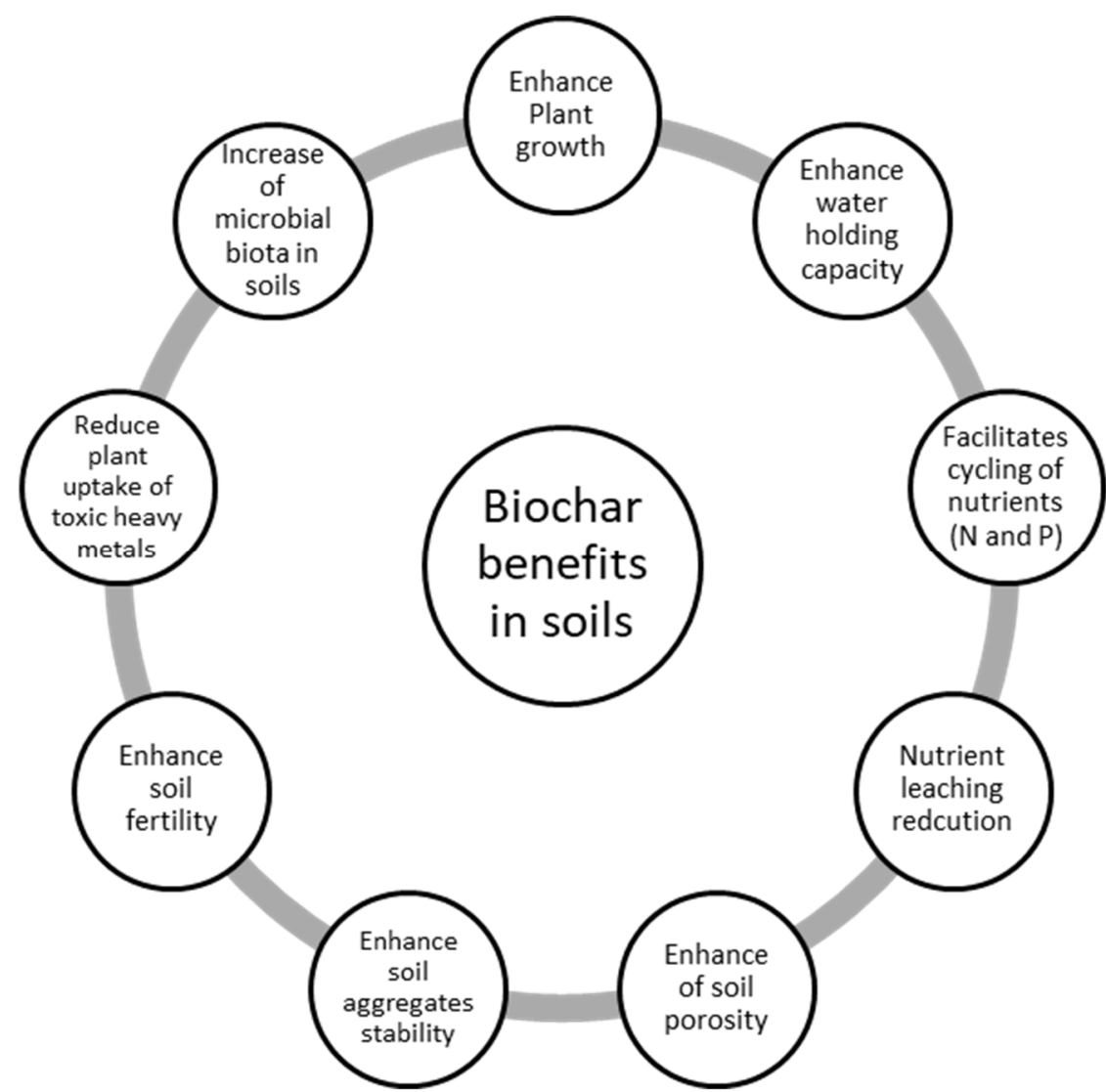

Figure 1. Potential biochar benefits in soils. Adapted from $[9,10,12]$.

For the synthesis of modified biochar, different kinds of biomass have been used, among these are sludge waste, agricultural waste (e.g., wheat, corn and sugar beet tailing), animal litter and wood waste. Wood waste has been used in different studies to harness its capacity for phosphate adsorption as well as its properties as biochar [12]. This material has various advantages for the production of biochar as it contains low moisture and ash content and has shown promising results for the adsorption of phosphate with adsorption concentrations of 118 and $142.7 \mathrm{mg}-\mathrm{P} \cdot \mathrm{g}^{-1}$ by woody biochar derived from oak sawdust and wood waste, respectively $[13,14]$.

Woody residue can be found in the form of sawdust, woodchip, shavings and bark. Apart from its low cost and high availability, hardwood has presented promising results when used for the synthesis of biochar for the adsorption of phosphate. Dugdug and Chang [15] concluded hardwood biochar had better performance in the adsorption of phosphate compared wheat straw biochar. Therefore, hardwood can be a potential candidate for low-cost biomass to produce modified biochar with the objective of phosphate delivery to crops. This can contribute to addressing the issue of a suitable end-use for this raw material, while acting as a potential source of phosphate for crops located in places under drought stress conditions. 


\subsection{Biomass Used to Produce Biochar for the Adsorption of Phosphate}

Biochar properties and its potential use as a soil amendment for the increase of nutrient availability depends significantly on the type of biomass employed for its synthesis as well as the pyrolysis conditions [15]. Biomass has significant effects on different properties of biochar, including ash content, $\mathrm{H} / \mathrm{C}$ ratio, $\mathrm{pH}$, surface area and cation and anion exchange capacity according to the authors of [16].

The selection of biomass is paramount to enhance the properties of biochar; the authors of [14] suggested biomass with low moisture content is suitable for biochar synthesis, as it requires low demand of heat energy and time for the pyrolysis, avoiding inhibition of char formation making it a low-cost process. Ash content can also be a determining factor for selecting a biomass source to produce biochar; the authors of [16] studied 12 different biochars produced from different feedstocks and concluded that biochar produced from feedstock with lower ash content can be easily applied in soils as there is less loss by wind. The study recommended woody-based biomass as it showed lower ash content than the non-woody biomass (turkey litter and walnut shell). Similar results are presented in [1], where oak wood biomass had lower ash content compared to greenhouse waste. Furthermore, woody biomass has been reported to produce biochars with higher surface area than other sources such as straw biochar, green waste biochar and algae biochar [16]. Biochar yield is also influenced by the type of feedstock employed. According to the authors of [12], higher yield production of biochar results from the pyrolysis of animal litter and solid wastes biomass than from crop and wood biomass. This can be related to the high inorganic content of waste-based biomass. Table 1 presents a summary of some of the promising material for biochar production for phosphate adsorption.

Table 1. Sources of biomass used for the synthesis of biochar for the adsorption of phosphate, pyrolysis temperature and time.

\begin{tabular}{|c|c|c|c|c|}
\hline Biomass & $\begin{array}{l}\text { Phosphate Adsorption } \\
\text { Capacity } \mathrm{mg}-\mathrm{P} \cdot \mathrm{g}^{-1}\end{array}$ & $\begin{array}{c}\text { Pyrolysis Temperature } \\
{ }^{\circ} \mathrm{C}\end{array}$ & Pyrolysis Time & References \\
\hline \multicolumn{5}{|c|}{ Agricultural waste } \\
\hline Soybean straw & 74.47 & 500 & $2 \mathrm{~h}$ & [6] \\
\hline Tobacco stems & 90.91 & 750 & $4 \mathrm{~h}$ & [17] \\
\hline \multicolumn{5}{|c|}{ Animal waste } \\
\hline Cow dung & 240.83 & 700 & $1 \mathrm{~h}$ & [18] \\
\hline \multicolumn{5}{|c|}{ Sludge waste } \\
\hline Waste activated sludge & 111 & 550 & $2 \mathrm{~h}$ & [19] \\
\hline \multicolumn{5}{|c|}{ Woody } \\
\hline Oak sawdust & 142.7 & 500 & $30 \mathrm{~min}$ & {$[20]$} \\
\hline Wood chips & 3.201 & 500 & $2 \mathrm{~h}$ & [21] \\
\hline \multicolumn{5}{|l|}{ Wood waste: Populus X } \\
\hline $\begin{array}{l}\text { Canadensis Moench and } \\
\text { Sophora japonica Linn }\end{array}$ & 118 & 600 & $1 \mathrm{~h}$ & [4] \\
\hline Oak chips & 46.37 & 500 & $30 \mathrm{~min}$ & [22] \\
\hline
\end{tabular}

\subsection{Adsorption of Phosphate by Biochar}

Efficient adsorption of phosphate by raw biochar is low due to its negatively charged surface, lack of compatible functional groups and imperfect porosity structure [5]. Therefore, it is necessary to chemically modify biochar to enhance its phosphate adsorption capacity. A variety of agents have been used to modify biochar to promote phosphate capture, as shown in Table 2, but the use of metals has been the most frequently employed technique because they present high efficiency, low cost and are abundant in the biosphere [23].

The use of magnesium $(\mathrm{Mg})$ has resulted in positive effects on the adsorption of phosphate by biochar. $\mathrm{Mg}$ is an abundant, environmentally friendly and low-cost material, with high affinity to phosphate [17]. Wu and Wei [5] reported that modified biochar with 
$\mathrm{MgO}$ adsorbed twice the rate of raw biochar. $\mathrm{Xu}$ and Zhang [4] compared the efficiency of different modification agents ( $\mathrm{Mg}, \mathrm{Al}, \mathrm{Fe}$ and $\mathrm{Ca}$ ) showing $\mathrm{Mg}$-biochar had the best phosphate adsorption capacity. Lanthanum (La), which is a relativity low-cost material, with low harm to the environment and is generally abundant, has also been used to modify biochar for phosphate adsorption. Wang and Guo [20] reported that La modified biochar has 4.5-fold improvement over raw biochar. Other agents used to modify the biochar to enhance it phosphate adsorption capacity include iron (Fe) and aluminium (Al). Table 2 presents some of the latest development in metal-biochar works for phosphate adsorption.

Table 2. P adsorption capacity of biochar using different modification agents.

\begin{tabular}{|c|c|c|c|}
\hline Biochar Feedstock & Modification/Activation Agents & $\begin{array}{l}\text { Phosphate Adsorption Capacity } \\
\qquad \mathrm{mg}-\mathrm{P} \cdot \mathrm{g}^{-1}\end{array}$ & References \\
\hline Ground corn biochar & $\mathrm{MgCl}_{2}$ & 239 & [24] \\
\hline Peanut-shells & $\mathrm{MgO}$ & 18.94 & [5] \\
\hline Poplar chips & $\mathrm{MgCl}_{2} \cdot 6 \mathrm{H}_{2} \mathrm{O}$ & 89 & [25] \\
\hline Holm oak & $\mathrm{MgCl}_{2} \cdot 6 \mathrm{H}_{2} \mathrm{O}$ & 64.6 & [26] \\
\hline Greenhouse paprika waste & $\mathrm{MgCl}_{2} \cdot 6 \mathrm{H}_{2} \mathrm{O}$ & 65.1 & [26] \\
\hline Bamboo feedstock & $\mathrm{Mg}-\mathrm{Fe} \mathrm{LDH}$ & 7.58 & {$[27]$} \\
\hline Bamboo feedstock & Mg-Al LDH & 13.11 & {$[27]$} \\
\hline Sesame straw & $\mathrm{MgO}$ & 8.42 & [28] \\
\hline Pineapple peels & $\mathrm{La}(\mathrm{OH})_{3}$ & 101.16 & [29] \\
\hline Sewage sludge & $\mathrm{La}(\mathrm{NO} 3)_{3}$ & 93.91 & [30] \\
\hline Oak chips & $\mathrm{La}(\mathrm{NO} 3)_{3}$ & 46.37 & {$[22]$} \\
\hline Phragmites australis & $\mathrm{LaCl}_{3} / \mathrm{Fe}_{3} \mathrm{O}_{4}$ & 25 & [31] \\
\hline Powdered straw & $\mathrm{LaFeO}_{3}$ & 209.25 & [32] \\
\hline Waste activated sludge & $\mathrm{FeSO}_{4} \cdot 7 \mathrm{H}_{2} \mathrm{O}$ and $\mathrm{FeCl}_{3} \cdot 6 \mathrm{H}_{2} \mathrm{O}$ & 34.2 & [19] \\
\hline Waste activated sludge & $\mathrm{FeCl}_{3} \cdot 6 \mathrm{H}_{2} \mathrm{O}$ & 111 & [19] \\
\hline Okara & $\mathrm{FeCl}_{3}$ & 4.785 & [33] \\
\hline Sludge-based biochar & $\mathrm{FeSO}_{4}$ & 3.14 & [34] \\
\hline Sludge-based biochar & $\mathrm{Fe}\left(\mathrm{NO}_{3}\right)_{3}$ & 2.34 & [34] \\
\hline Corn cobs & $\mathrm{Fe}\left(\mathrm{NO}_{3}\right)_{3}$ & 1.99 & [21] \\
\hline Garden wood waste & $\mathrm{Fe}\left(\mathrm{NO}_{3}\right)_{3}$ & 2.75 & [21] \\
\hline Wood chips & $\mathrm{Fe}\left(\mathrm{NO}_{3}\right)_{3}$ & 3.2 & [21] \\
\hline Cotton stalk & $\mathrm{FeCl}_{3}$ & 0.399 & [35] \\
\hline Poultry manure & $\mathrm{AlCl}_{3}$ & 701.65 & [36] \\
\hline Industrial tea waste & $\mathrm{Al}\left(\mathrm{NO}_{3}\right)_{3} .9 \mathrm{H}_{2} \mathrm{O}$ & 5 & [37] \\
\hline Sludge-based biochar & $\mathrm{Al}\left(\mathrm{NO}_{3}\right)_{3}$ & 2.69 & [34] \\
\hline
\end{tabular}

\subsection{Desorption of Phosphate by Biochar}

The desorption process of phosphate by modified biochar is important to understand its potential use as a fertiliser and soil amendment. Different factors can affect the desorption process of nutrients from biochar such as pyrolysis temperature, type of biomass employed and biochar application rate [9]. However, in the literature, studies regarding desorption of phosphate by modified biochar are limited. The information focuses on biochar's recyclability and reusability for the adsorption of phosphate, the cost-efficiency of the adsorption process and the benefits of biochar application for crop development and soil function [3]. Few studies focused on the release of phosphate from biochar for its potential use as a slow-release fertiliser. Hale and Alling [38] reported cacao shell biochar had a phosphate desorption value of $1.48 \mathrm{mg} \cdot \mathrm{g}^{-1}$ and corn cob $0.172 \mathrm{mg} \cdot \mathrm{g}^{-1}$ in two months. Fang et al. [39] reported that the release rate of phosphate by $\mathrm{Mg}$ biochar at different pyrolysis temperatures 300,450 and $600{ }^{\circ} \mathrm{C}$ were $3.3 \%\left(8 \mathrm{mg} \cdot \mathrm{g}^{-1}\right), 3.9 \%\left(9.2 \mathrm{mg} \cdot \mathrm{g}^{-1}\right)$ and $4.4 \%\left(10.8 \mathrm{mg} \cdot \mathrm{g}^{-1}\right)$, respectively, over a period of $90 \mathrm{~h}$. However, it is important to note that the latter experiments were carried at acidic conditions.

Other studies related to desorption of phosphate have not reported the rate of phosphate release from biochar. Morales and Comerford [11] developed a study of adsorption and desorption of phosphate focused on comparing three different feedstock at different 
pyrolysis temperatures. However, desorption analysis was more concentrated on how the biochar characteristics influenced phosphate release rates. Takaya and Fletcher [1] also analysed the desorption process of modified biochar. However, they reported further investigation is required to know its potential uses as a soil fertiliser. Chen and Qin [18] studied the potential of engineered biochar from agricultural waste (cow dung) for the slow release of phosphate and its use as a fertiliser. Biochar produced from cow dung when used as fertiliser in lettuce crops improved phosphate availability, soil $\mathrm{pH}$, soil moisture content and organic carbon content, as well as crop growth and yield.

Despite the promising results, no studies have been conducted to evaluate the desorption rate of modified biochar employing post-treatment by modification agents to enhance its capacity as a potential slow nutrient carrier. Hence, the objective of this project was to synthesise a biochar for the effective adsorption and release of phosphate. In this paper, we report on adsorption and desorption behaviour for a Mg-treated biochar. We envisage that our work will help improve understanding of phosphate availability in agronomic settings, which is highly relevant as alternative and resilient phosphorus fertilisers are sought.

\section{Materials and Methods}

\subsection{Biochar Preparation and $\mathrm{MgCl}_{2}$ Modified Biochar Preparation}

Eucalypt stem tree chips were obtained locally, to produce HW-biochar and HWmodified biochar. This raw material was washed with deionised water (DW) to remove impurities and then oven dried at $105^{\circ} \mathrm{C}$ for approximately $24 \mathrm{~h}$. Measured quantities of the biomass was pyrolysed at three different temperatures 350,450 and $550{ }^{\circ} \mathrm{C}$ in a tube furnace in an oxygen starved environment. Pyrolysis was carried out for $1.5 \mathrm{~h}$ at $10^{\circ} \mathrm{C} / \mathrm{min}$, and then the furnace was allowed to cool to room temperature to retrieve the samples. The yield is calculated as follows:

$$
\text { Yield }_{\text {Biochar }}=\frac{m_{\text {biochar }}}{m_{\text {raw biomass }}} \times 100 \%
$$

where Yield Biochar $_{\text {is }}$ the mass yield of biochar in per cent, $m_{\text {biochar }}$ is mass of biochar in $g$ and mraw biomass is the mass of raw biomass in $\mathrm{g}$.

The biochar samples were crushed and sieved into small pieces of $0.5-0.2 \mathrm{~mm}$ size. Biochar samples were then submerged in $0.5 \mathrm{M} \mathrm{HCl}$ at a ratio of $1 \mathrm{~g}: 10 \mathrm{~mL}$ for $24 \mathrm{~h}$ to remove impurities and ash and enhance the porous structure. Then, samples were rinsed with DW to remove impurities and oven dried at $105^{\circ} \mathrm{C}$. The raw biochar samples were stored in labelled airtight plastic containers. The modified biochar was prepared by impregnation following procedure described in [24] with slight modification. Briefly, biochar was soaked in $1 \mathrm{M} \mathrm{MgCl}_{2}$ solution prepared by dissolving $203.3 \mathrm{~g}$ of $\mathrm{MgCl}_{2} \cdot 6 \mathrm{H}_{2} \mathrm{O}$ in $1000 \mathrm{~mL}$ of DW. The raw biochar sample was submerged into the $\mathrm{MgCl}_{2}$ [4], with constant shaking for $24 \mathrm{~h}$. Then, the samples were filtered with $90 \mathrm{~mm}$ Whatman filter paper, and modified biochar was oven dried at $105^{\circ} \mathrm{C}$ for $24 \mathrm{~h}$ and stored in containers labelled as $\mathrm{Mg}$-Biochar.

\subsection{Biochar Characterisation and Proximate Analysis}

The $\mathrm{pH}$ of the samples was determined according to the ASTM Standard Method (D3838-05). First, $0.1 \mathrm{~g}$ of each sample were added to $10 \mathrm{~mL}$ of DW followed by shaking. Then, $\mathrm{pH}$ was measured using a $\mathrm{pH}$ meter. Fourier-transform infrared spectroscopy (FTIR) was employed for the characterisation of the functional groups of the biochar samples.

Ash content (ASH) of biochar was measured following the ASTM Standard method (D3174) by calculating the difference between the masses after combustion of $1 \mathrm{~g}$ of the sample in the furnace at $650{ }^{\circ} \mathrm{C}$ for $3 \mathrm{~h}$. The volatile matter (VM) was determined following the ASTM Standard method (D1762-84) by calculating the mass difference after the combustion of $1 \mathrm{~g}$ of sample in the furnace at $350{ }^{\circ} \mathrm{C}$ for $3 \mathrm{~min}$. Fixed carbon content was calculated as the difference of the total original weigh of the sample and the sum of ASH and VM. Scanning electron microscope (SEM) imaging were used to inspect the surface and structure of the biochar. 


\subsection{Specific Surface Area and Electron Microscopy}

The BET specific surface area (SSA) and pore volume of raw biochar and Mg-biochar was determined using $\mathrm{N}_{2}$ adsorption at $77 \mathrm{~K}$ (Micrometrics TriStar II 3020 3.02, Norcross, GA, USA). Electron microscopy images and scans were obtained using a JEOL JSM7100F scanning electron microscope

\subsection{Point of Zero Charge $\left(\mathrm{pH}_{\mathrm{PZC}}\right)$}

The Point of zero charge of raw biochar and modified biochar was measured according to procedure described in [39]. First, $0.15 \mathrm{~g}$ of each biochar were mixed with $15 \mathrm{~mL}$ of $0.01 \mathrm{M} \mathrm{NaCl}$ solution with $\mathrm{pH}$ range from 2 to 12 . The $\mathrm{pH}$ was adjusted using $0.1 \mathrm{M}$ of $\mathrm{HCl}$ and $\mathrm{NaOH}$. The final $\mathrm{pH}$ of the solution was measured after $24 \mathrm{~h}$ of shaking.

\subsection{Phosphate Adsorption Screening Experiments}

Phosphate solution was prepared by dissolving $176.16 \mathrm{~g}$ potassium phosphate dibasic anhydrous (K2HPO4) in $1 \mathrm{~L}$ of DW for the adsorption experiments. Working solutions were prepared from the stock solution as needed. Screening tests were performed to determine the biochar with the highest potential for further investigation; $0.2 \mathrm{~g}$ of the samples were loaded into a flask with $20 \mathrm{~mL}$ of the phosphorus solution with a concentration of $30 \mathrm{mg} \cdot \mathrm{L}^{-1}$. Then, the containers were put in a shaker and mixed vigorously at room temperature for $24 \mathrm{~h}$. The phosphate adsorption performance was calculated by the difference in concentration between the initial concentration of phosphate and the final concentration. The amount of $\mathrm{P}$ adsorbed by the biochar samples $\left(q_{e}\right)$ was calculated using Equation (2):

$$
q_{e}=V\left(C_{0}-C_{e}\right) / M
$$

where $q_{e}\left(\mathrm{mg} \cdot \mathrm{g}^{-1}\right)$ is the amount of $\mathrm{P}$ adsorbed on biochar, $\mathrm{C}_{0}\left(\mathrm{mg} \cdot \mathrm{L}^{-1}\right)$ is the initial concentration of $\mathrm{P}$ in the solution at starting time $(\mathrm{t}=0), C_{e}\left(\mathrm{mg} \cdot \mathrm{L}^{-1}\right)$ is the final concentration, $V(\mathrm{~L})$ is the volume of the $\mathrm{P}$ solution and $\mathrm{M}(\mathrm{g})$ is the mass of biochar added.

Phosphate concentration was measured following APHA 2005 standard methods. Internal standards were used to validate the results (concentration 0 to $1 \mathrm{mg} \mathrm{PO}_{4}-\mathrm{P} \cdot \mathrm{L}^{-1}$ ). To determine $\mathrm{PO}_{4}-\mathrm{P}$, samples were withdrawn using $0.45 \mu \mathrm{m}$ filter syringe. The filtered solutions were then analysed using colorimetric methods with a Discrete Chemistry Analyser (Westco Smartchem 200, Danbury, CT, USA). All $\mathrm{PO}_{4}{ }^{3-}$ values are reported as mg-PO ${ }_{4}-\mathrm{P}$.

\subsection{Adsorption Kinetics}

$P$ adsorption kinetics was studied following the procedure of Li et al. [26], in which $0.2 \mathrm{~g}$ of the biochar sample were added to a solution of $20 \mathrm{~mL}$ of a $30 \mathrm{mg} \mathrm{PO} 4-\mathrm{P} \cdot \mathrm{L}^{-1}$ phosphate solution in a $100 \mathrm{~mL}$ flask and then shaken at room temperature. The samples were drawn at 5, 10, 20, 30, 60, 120 and $240 \mathrm{~min}$ and $24 \mathrm{~h}$. The kinetics of the adsorption of P were modelled using the pseudo-first- and pseudo-second-order equations (Equations (3) and (4)).

Pseudo-first-order equation:

$$
q_{t}=q_{e}\left(1-e^{-k t}\right)
$$

Pseudo-second-order equation:

$$
q_{t}=\frac{K_{2} q_{e}^{2} t}{1+K_{2} q_{e} t}
$$

where $q_{t}$ is the adsorption capacity at time $t\left(\mathrm{mg} \cdot \mathrm{g}^{-1}\right) . k$ and $K_{2}$ are the rate constant of pseudo-first order and pseudo-second order, respectively. $t$ is the time ( $\mathrm{min}$ ).

\subsection{Adsorption Isotherms}

Following the procedure in [25] with modifications, $0.2 \mathrm{~g}$ of the adsorbent were added to $20 \mathrm{~mL}$ of $\mathrm{PO}_{4}$-P solution at different concentrations $\left(5,10,15,30\right.$ and $\left.50 \mathrm{mg} \mathrm{PO}_{4}-\mathrm{P} \cdot \mathrm{L}^{-1}\right)$ 
as well as $30 \mathrm{~g} \mathrm{PO}_{4}-\mathrm{P} \cdot \mathrm{L}^{-1}$. The $\mathrm{pH}$ was adjusted by adding $0.1 \mathrm{M}$ of $\mathrm{NaOH}$ or $\mathrm{HCl}$ as required to maintain $\mathrm{pH} \sim 6$. The samples were drawn, and the total $\mathrm{P}$ concentration was measured as described previously. The results were fitted to the Langmuir and Freundlich isotherms models (Equations (5) and (6), respectively):

Langmuir equation:

$$
q_{e}=\frac{q_{\max } K_{L} C_{e q}}{1+K_{L} C_{e q}}
$$

where $q_{\max }\left(\mathrm{mg} \cdot \mathrm{g}^{-1}\right)$ is the monolayer adsorption capacity, $C_{e q}\left(\mathrm{mg} \cdot \mathrm{L}^{-1}\right)$ is the equilibrium concentration of the adsorbate $\left(\mathrm{mg} \cdot \mathrm{g}^{-1}\right)$ and $K_{L}\left(\mathrm{~L} \cdot \mathrm{mg}^{-1}\right)$ is the Langmuir constant.

Freundlich equation:

$$
q_{e}=K_{F} C_{e q}^{\frac{1}{n}}
$$

where $K_{F}$ is the distribution coefficient (Freundlich adsorption constant) and $\mathrm{n}$ is the correction factor.

\subsection{Phosphate Desorption Experiments}

The desorption experiments were conducted to study the slow-release capacity of biochar. Biochar was first loaded with phosphate by soaking biochar samples in phosphate solutions ( 20 and $40 \mathrm{mg} \cdot \mathrm{L}^{-1}$ ) for $24 \mathrm{~h}$ at $\mathrm{pH}=6$. The loaded biochar was first rinsed with DI water and then dried in the oven for $2 \mathrm{~h}$ at $105^{\circ} \mathrm{C}$. The amount of phosphate adsorbed onto the biochar were determined by measuring the concentration remaining in the solution. Then, $0.2 \mathrm{~g}$ of biochar samples were added to $20 \mathrm{~mL}$ DI water and left for different periods of time $(5,30,60,180,360$ and $1440 \mathrm{~min})$ at two different $\mathrm{pH}$ values (7 and 4.6) to simulate the potential release of phosphate in neutral and acidic environments. The final concentration was measured. The amount of phosphate released can be calculated as $\mathrm{m}=\mathrm{C} \times \mathrm{V}$, where $\mathrm{C}$ is the concentration and $\mathrm{V}$ is the volume.

\subsection{Desorption Kinetics Modelling}

To model the kinetics of phosphate desorption, the first rate of decay (FRD) and the two-compartment first-order rate constant (TFRC) models were used. The FRD model is a commonly used decay model which assumes constant rate of release $(\mathrm{k})$ of the adsorbate from the adsorbent over time. The FRD model is mathematically presented as:

$$
q_{t}=q_{0} e^{-k t}
$$

TFRC is one of the most common empirical equations to obtain the desorption rates [40]. The model assumes bi-phasic release of adsorbate and is represented in the following equation:

$$
\frac{q_{t}}{q_{0}}=a e^{-k_{f} t}+(1-a) e^{-k_{s} t}
$$

$q_{t}$ is the adsorbate mass per mass adsorbent remaining in the solid phase $\left(\mathrm{mg} \cdot \mathrm{g}^{-1}\right)$ at time $t ; q_{0}$ is the initial adsorbate mass held by the adsorbent $\left(\mathrm{mg} \cdot \mathrm{g}^{-1}\right) ; a$ is the fraction of the fast-desorbing adsorbate; $k_{f}$ is the first-order desorption rate constant of the fast-desorbing adsorbate $\left(\mathrm{min}^{-1}\right)$; and $k_{s}$ is the first-order decay rate of the slow-release adsorbate $\left(\mathrm{min}^{-1}\right)$.

\subsection{Quality Control and Data Analysis}

All experiments were run in duplicate and average values are reported. If the difference between the duplicates was more than $10 \%$, the experiment was repeated. To compare the results and determine the significance of the differences before and after treatment, student $t$-test was used. Analysis of the variance (One-way ANOVA) was used to compare the performance of the different biochars. Significance level $(\alpha=0.05)$ was used in all statistical tests. 


\section{Results and Discussion}

\subsection{Biomass and Biochar Properties}

The composition of biomass is presented in Table 3. The moisture content of the biomass was $1.73 \%$. Low moisture content is commonly reported in the literature for wood waste biomass $[13,14]$. The ash content $(31.5 \%)$ is similar to results reported by Chen and Chen [41] for hardwood (38.55\%). Biochar yield for the three different pyrolysis temperatures 350,450 and $550{ }^{\circ} \mathrm{C}$ are shown in Table 3. Biochar yield had an inverse relation with pyrolysis temperature. This behaviour was expected as wood biomass has a high content of cellulose, lignin and hemicellulose [14,42]. In addition, a decrease in yield as the temperature increased can be attributed to great decomposition of primary biomass or to secondary decomposition of biochar according to Ola and Jekayinfa [43]. The $\mathrm{P}$ content in the raw biochar ranged $0.0482-0.345 \mathrm{mg} \cdot \mathrm{g}^{-1}$, as shown in Table 3. Experiments were performed to determine the amount of $\mathrm{P}$ released from raw biochar to evaluate its availability. The release of $\mathrm{P}$ from biochar was very low, thus it is unlikely to be readily available.

Table 3. Proximate composition of biochar at different temperatures.

\begin{tabular}{|c|c|}
\hline \multicolumn{2}{|c|}{ Proximate Analysis of Dry Biomass (\% Dry Basis) } \\
\hline Ash content & $31.5 \%$ \\
\hline Fixed carbon & $21 \%$ \\
\hline Volatile matter & $47.1 \%$ \\
\hline \multicolumn{2}{|c|}{ Yield (\%) } \\
\hline HW-350 & $71.94 \%$ \\
\hline $\mathrm{HW}-450$ & $38.21 \%$ \\
\hline HW-550 & $35.81 \%$ \\
\hline \multicolumn{2}{|c|}{ Amount of $P\left(\mathrm{mg} \cdot \mathrm{g}^{-1}\right)$} \\
\hline HW-350 & 0.0482 \\
\hline $\mathrm{HW}-450$ & 0.0766 \\
\hline HW-550 & 0.345 \\
\hline
\end{tabular}

The $\mathrm{pH}$ of biochar prepared at 350,450 and $550{ }^{\circ} \mathrm{C}$ was alkaline in nature with values $8.1,8.2$ and 8.4 , respectively. The increase in $\mathrm{pH}$ values with increase in pyrolysis temperature can be caused by the separation of alkali salts from organic materials, as well as the loss of acidic functional groups and the appearance of basic functional groups [42,44]. Oginni and Yakaboylu [45] reported an increase in $\mathrm{pH}$ after pyrolysis of wood biomass from longleaf pine, red oak and hard maple at $500{ }^{\circ} \mathrm{C}$; their $\mathrm{pH}$ values were 8.6, 9.0 and 9.8, respectively. The modified biochar, $\mathrm{Mg}$-biochar, had alkaline nature $(\mathrm{pH}=8.5)$. Generally, very little change in the $\mathrm{pH}$ was observed after the modification process.

Figure 2 shows the SEM and EDS spectrum of the biochar (before modification) with $\mathrm{MgCl} 2$ and after modification (Mg-Biochar). The SEM scans reveal that the pore size of the Mg-Biochar is larger and more developed. Furthermore, the EDS spectra confirms that the $\mathrm{Mg}$ presence is more prominent in the Mg-Biochar than in the unmodified biochar.

The specific surface area of the biochar prepared at $500{ }^{\circ} \mathrm{C}$ was $1.49 \mathrm{~m}^{2} \cdot \mathrm{g}^{-1}$ and the pore volume is $0.000427 \mathrm{~m}^{3} \cdot \mathrm{g}^{-1}$. Similar results were reported for brown marine macroalgae and woody derived biochar by Oginni and Yakaboylu [45] and Jung and Ahn [7] with SSAs of 2.39 and $0.26 \mathrm{~m}^{2} \mathrm{~g}^{-1}$, respectively. For the Mg-biochar $\left(500{ }^{\circ} \mathrm{C}\right.$ ) produced here, the SSA was $0.97 \mathrm{~m}^{2} \cdot \mathrm{g}^{-1}$ and the pore volume was $0.0003 \mathrm{~m}^{3} \cdot \mathrm{g}^{-1}$. The development of larger pores with wider diameters in the modified can explain the reduction in the BET SSA. As the pore diameter grew, it consumed the smaller pores surrounding it, resulting in loss of nano-surface area. This is not necessarily bad because, for many of the small pores, despite providing higher surface area, the surface area and the active sites within them may not be accessible. Other studies have reflected the influence of residence time and pore clogging to be the some of the causes that affect SSA. Lu and Zong [46] 
reported an increase of SSA in maize straw and rice biochar pyrolysed at $550{ }^{\circ} \mathrm{C}$ when residence time was increased from 2 to $5 \mathrm{~h}$. Li and Dong [47] noted how high pyrolysis temperatures can cause the pores to collapse reducing the SSA of biochar. Furthermore, it is important to note that the MB method measures the mesoporous surface area of the biochar, which means MB may not reflect the total surface area available for adsorption which includes the micropores. It was also found that the $\mathrm{pH}_{\mathrm{pzc}}$ of the biochar increased from 7 (raw) to 8 for the Mg-biochar $\left(550^{\circ} \mathrm{C}\right.$ ), as shown in Figure 3.
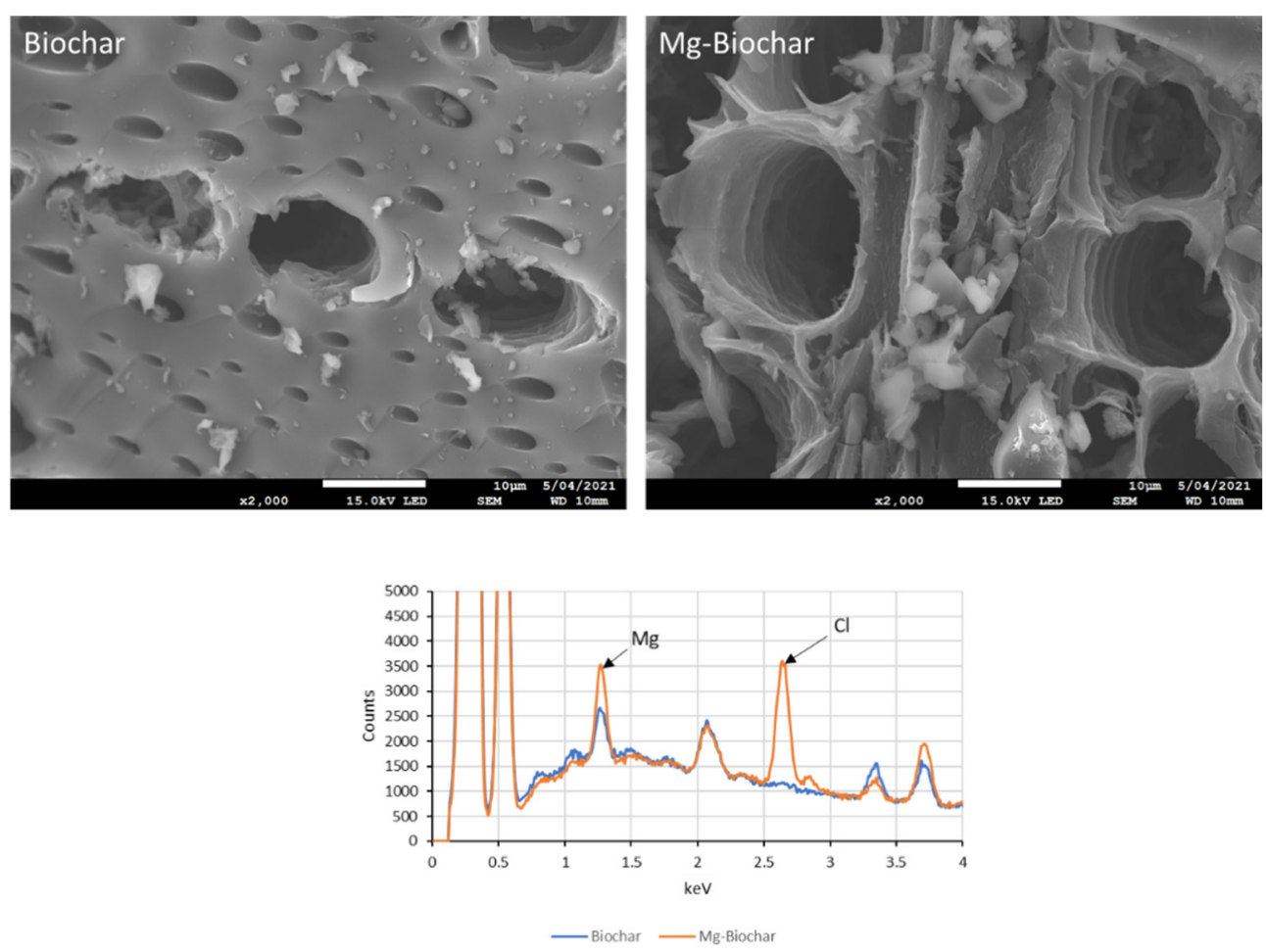

Figure 2. SEM scans and EDS spectrum of the biochar before and after modification.

FTIR analysis was performed to analyse the functional groups in both raw and modified biochar. The resulting FTIR spectra are shown in Figure 4. Biochar produced at $350{ }^{\circ} \mathrm{C}$ exhibited a broad band between 3000 and $3500 \mathrm{~cm}^{-1}$ (peak maximum at $3327 \mathrm{~cm}^{-1}$ ) which represents vibrations of hydrogen-bonded $\mathrm{O}-\mathrm{H}$ groups (alcoholic and phenolic) as well as the double-bonded groups $\mathrm{C}=\mathrm{O}$ broad band between 1500 and $2000 \mathrm{~cm}^{-1}$ (peak maximum at $1689 \mathrm{~cm}^{-1}$ ) [14]. For all raw biochar, adsorption in the region between 2843 and $2981 \mathrm{~cm}^{-1} \mathrm{C}-\mathrm{H}$ stretching is allocated to aliphatic functional groups and another strong band at $1055 \mathrm{~cm}^{-1}$ represents the $\mathrm{C}-\mathrm{O}$ stretching oxygenated groups. The strong band at $1224 \mathrm{~cm}^{-1}$ represents phenolic $-\mathrm{OH}$ groups [42]. As temperature increases from 350 to $550^{\circ} \mathrm{C}, \mathrm{OH}$ functional groups, as well as $\mathrm{C}=\mathrm{O}$ groups, decrease.

The strong aromatic band of $\mathrm{C}=\mathrm{C}$ at $1602 \mathrm{~cm}^{-1}$ is observed in the biochar synthesised at $350{ }^{\circ} \mathrm{C}$, and this vibration is strongly present until the temperature reached $550{ }^{\circ} \mathrm{C}$, at which the band is reduced. This behaviour in biochar produced at high temperatures can be related to their low $\mathrm{H} / \mathrm{C}$ ratio according to Zhang and Chen [48]. The intensities of C-H (2843 and $\left.2981 \mathrm{~cm}^{-1}\right)$ aliphatic stretching, -OH phenolic $\left(1224 \mathrm{~cm}^{-1}\right)$ and C-O bands $\left(1055 \mathrm{~cm}^{-1}\right)$ exhibited a significant decrease because of the dehydration and degradation of ligneous and cellulosic compounds [43]. Functional groups present after modification of biochar by $\mathrm{MgCl}_{2}$ and adsorption of phosphorus are shown in Figure 4. There is a significant peak for all biochar in the band stretching from 1500 to $2000 \mathrm{~cm}^{-1}\left(1578 \mathrm{~cm}^{-1}\right)$, indicating functional groups $\mathrm{C}=\mathrm{C}$ and $\mathrm{C}=\mathrm{O}$ aromatic bonds for modified biochar and modified biochar loaded with phosphorus as well as for raw biochar loaded with phosphorus. For modified biochar in the bands of 3299 and $699 \mathrm{~cm}^{-1}$, groups assigned $\mathrm{Mg}-\mathrm{OH}$ and 
$\mathrm{Mg}-\mathrm{O}$ were detected confirming the incorporation of $\mathrm{Mg}$ in the biochar [25,49]. Another significant change for biochar after modification was a sharp increase in the band $1577 \mathrm{~cm}^{-1}$ for all biochar samples except raw biochar, which can be attributed to the aromatic functional groups $\mathrm{C}=\mathrm{C}$ and $\mathrm{C}=\mathrm{O}$. Compared with raw biochar, $\mathrm{Mg}$-biochar contained groups in the intensity bands from 2500 to $3000 \mathrm{~cm}^{-1}\left(2906 \mathrm{~cm}^{-1}\right)$ and 1000 to $1500 \mathrm{~cm}^{-1}$ and these were assigned to $\mathrm{CH}_{2}$ groups and $\mathrm{C}-\mathrm{O}$ groups [50]. After the $\mathrm{HW}$-biochar and $\mathrm{Mg}$-biochar were loaded with phosphorus, a significant increase in the stretching bands of 1408, 1023, 874 and $559 \mathrm{~cm}^{-1}$ were observed for HW-biochar with functional groups $\mathrm{C}-\mathrm{H}$ alkene, $\mathrm{C}-\mathrm{O}$ and $\mathrm{C}-\mathrm{H}$ aromatic out of plane. Regarding modified biochar, with the loading of $\mathrm{P}$, the peaks located at 3299 and $699 \mathrm{~cm}^{-1}$ disappeared, indicating this group can be linked to the adsorption of phosphorus into the Mg-biochar [25].

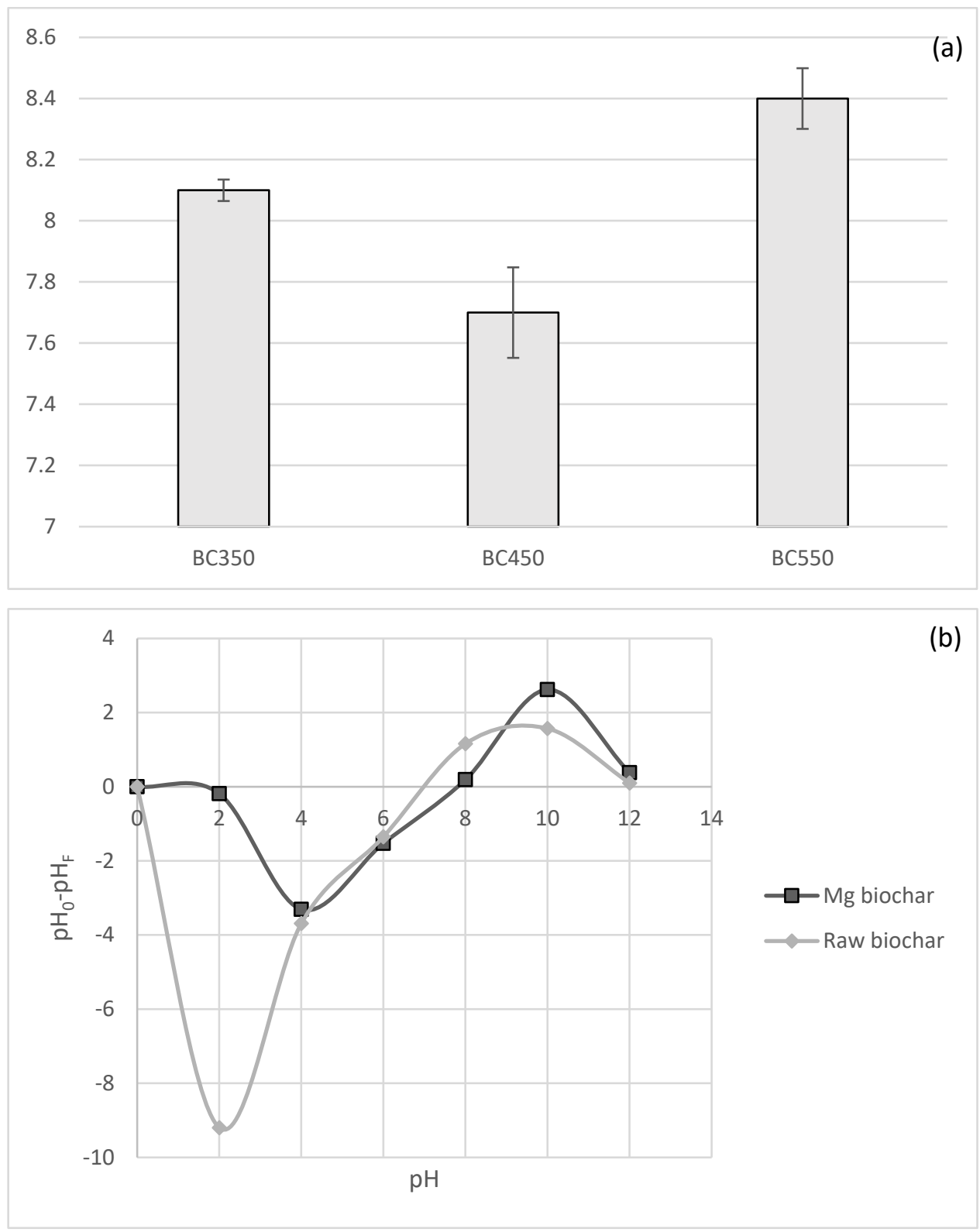

Figure 3. (a) $\mathrm{pH}$ values of raw biochar obtained from the pyrolysis of hardwood; and (b) point of zero charged $\mathrm{pH}_{\mathrm{PZC}}$ from raw biochar and modified biochar $\left(550{ }^{\circ} \mathrm{C}\right)$. 


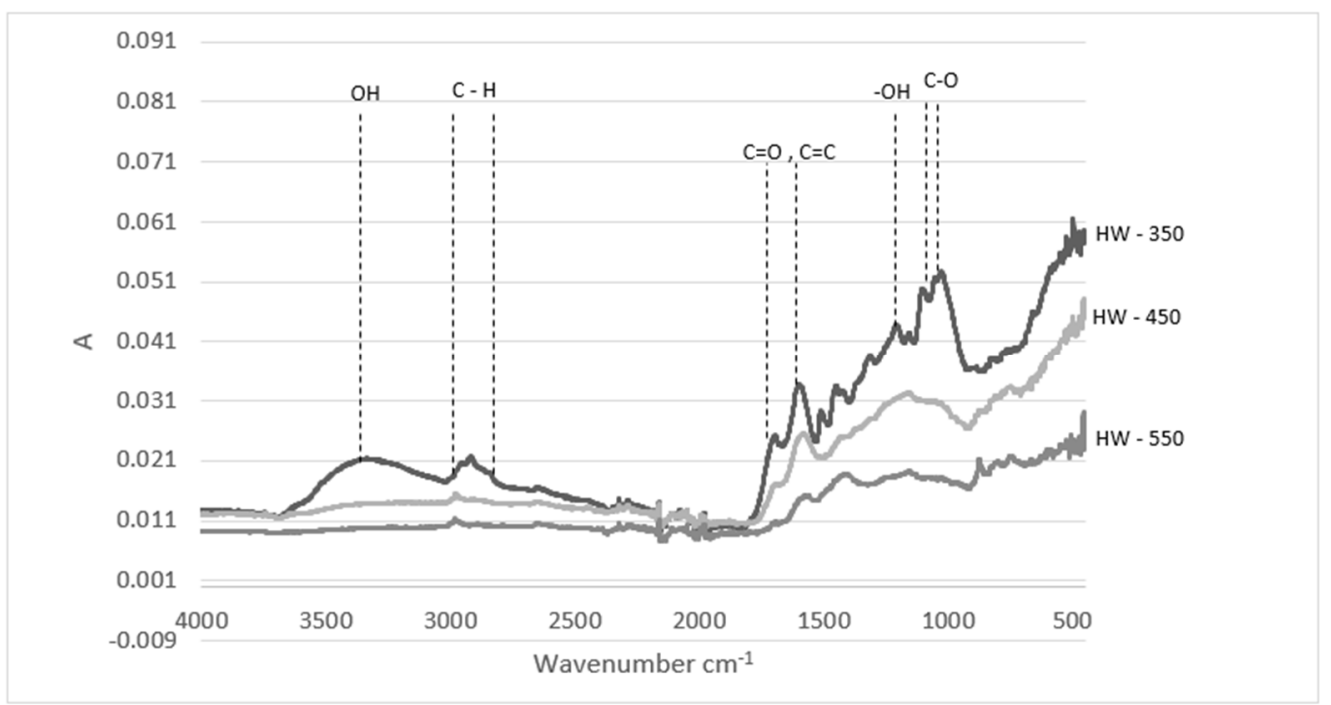

(a)

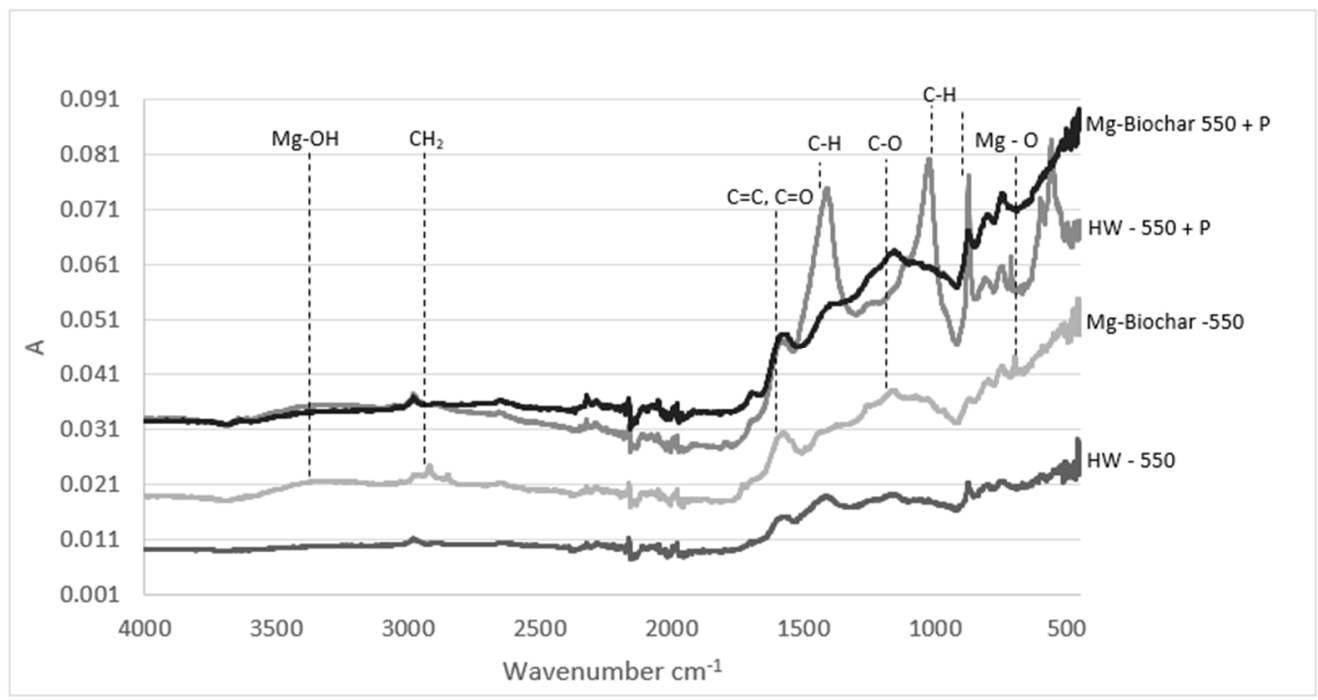

(b)

Figure 4. Fourier-transform infrared spectroscopy: (a) biochars prepared at different pyrolysis temperatures; and (b) modified and unmodified biochar before and after $\mathrm{P}$ adsorption.

\subsection{Adsorption of Phosphorus by HW-Biochar and Mg-Biochar}

The phosphorus adsorption capacities of raw biochar (HW-biochar) and $\mathrm{Mg}$ modified biochar (Mg-biochar) are shown in Figure 5. The raw biochar pyrolysed at 350 and $450{ }^{\circ} \mathrm{C}$ showed low adsorption capacity ( 0.26 and $0.25 \mathrm{mg}-\mathrm{P} \cdot \mathrm{g}^{-1}$, respectively), as shown in Figure $5 \mathrm{a}$. On the other hand, raw biochar synthesised at $550{ }^{\circ} \mathrm{C}$ showed the highest adsorption of phosphorus with $0.44 \mathrm{mg}-\mathrm{P} \cdot \mathrm{g}^{-1}$; although the ANOVA test failed to confirm that the results were significantly different $(p=0.22)$, the BC550 adsorbed almost double the amount of phosphate compared to the other biochars. As pyrolysis temperature increases, biochar surface area and pore formation increase enhancing biochar adsorption capacity of phosphorus [26,51]. Similar results were found by Zhou and Xu [52] and Yin and Liu [25] with the increase in adsorption capacity of $\mathrm{P}$ for raw biochar with an increase in pyrolysis temperature. Because of its adsorption capacity, $\mathrm{HW}$-biochar at $550^{\circ} \mathrm{C}$ was chosen to be modified with $\mathrm{Mg}$.

Biochar pyrolysed at $550{ }^{\circ} \mathrm{C}$ was selected to be modified with $\mathrm{MgCl}_{2}$. Modified biochar with $\mathrm{Mg}$ showed an increase in the adsorption of $\mathrm{P}$ from 0.44 to $0.59 \mathrm{mg}-\mathrm{P} \cdot \mathrm{g}^{-1}$ (Figure 5). Although t-test failed to confirm the significance of the improvement $(p=0.2)$, the change represents $34 \%$ improvement over unmodified biochar. Improvement in the performance of biochar by the addition of $\mathrm{Mg}$ has been presented in the literature. Fang 
and Zhang [24] reported maximum adsorption of $\mathrm{P}$ of modified corn biochar was higher compared to raw biochar (239 and $225 \mathrm{mg} \cdot \mathrm{g}^{-1}$ ). Similar results were published by Yin and Liu [25], describing biochar modified with $\mathrm{Mg}$ dramatically increased phosphate adsorption. However, the results reported in $[24,25]$ were obtained using extremely high initial concentrations of phosphate solutions. The Mg-biochar developed in this study was also able to achieve $238 \mathrm{mg} \cdot \mathrm{g}^{-1}$ when it was subjected to $\mathrm{PO}_{4}-\mathrm{P}$ solution with initial concentration of $30 \mathrm{~g} \cdot \mathrm{L}^{-1}$. The dramatic increase may be explained by the increased driving force due to the extreme difference between the $\mathrm{PO}_{4}-\mathrm{P}$ concentration in the solid and liquid phases. The modification with magnesium proved to be crucial for enhancing the adsorption capacity of raw biochar as it increased the positive surface charge on the biochar, thus increasing the tendency to attract anions. Mg modified biochar in the literature has shown a high affinity to anions due to the high $\mathrm{pH}_{\mathrm{PZC}}$ (12), as this causes the surface to be positively charged $[45,53]$. In our study, the $\mathrm{HW}$-biochar and $\mathrm{Mg}$-biochar $\mathrm{pH}_{\mathrm{PZC}}$ values were 7.0 and 7.9. As the $\mathrm{pH}_{\mathrm{PZC}}$ was higher than $\mathrm{pH}$ from the solution $(\mathrm{pH}=5)$, a positive surface in the Mg-biochar can be expected, which, due to electrostatic adsorption between the adsorbate and the biochar, can contribute to improving adsorption of $\mathrm{PO}_{4}{ }^{3-}[6,25]$. Moreover, the adsorption of phosphate increased 34\% over the raw biochar to Mg-biochar despite the decrease in the SSA.

Figure 6 shows the EDS spectra of the biochar before and after adsorption. It can be seen that $\mathrm{Mg}$ has played a role in phosphate adsorption in the unmodified and modified biochar. However, $\mathrm{Mg}^{\prime}$ s role can be easily seen in the modified biochar with the peak around 1.27 (corresponding to $\mathrm{Mg}$ ) disappearing after adsorption. It can also be seen that the chloride (around 2.65) and calcium (3.73) have also have been involved in the adsorption of phosphate. Marshall and Morton [54] proposed a multi-step mechanism for the formation of calcium phosphate on biochar in which $\mathrm{Cl}^{-}$played an important role. We propose a similar mechanism for the formation of magnesium phosphate on biochar.

\subsection{Adsorption Isotherms}

Figure 7 shows the adsorption isotherm for the Mg-modified biochar produced at $550{ }^{\circ} \mathrm{C}$. The isotherm parameters for both models, including the determination coefficients $\left(R^{2}\right)$ and the root mean squared error (RMSE), are presented in Table 4. The Langmuir model describes homogenous adsorption in which all sites have equal affinity for the adsorbate [55]. On the other hand, the Freundlich model describes multilayer adsorption but with non-uniform distribution implied. The Langmuir maximum adsorption capacity of Mg-biochar was $463.5 \mathrm{mg} \mathrm{PO}-\mathrm{P} \cdot \mathrm{g}^{-1}$; however, this is unlikely to be achieved at realistic $\mathrm{P}$ concentrations. To confirm this, an adsorption experiment was conducted with initial $\mathrm{PO}_{4}-\mathrm{P}$ concentration $30 \mathrm{~g} \cdot \mathrm{L}^{-1}$ and found $\mathrm{q}_{\mathrm{e}}$ to be $283 \mathrm{mg} \cdot \mathrm{g}^{-1}$. This behaviour may suggest that the adsorption is not conformant to Type I adsorption isotherm, which may violate the inherent assumption of Langmuir and Freundlich isotherm equations of Type I adsorption. Therefore, the results of the fitting from the models used in this study should be interpreted with caution. Table 5 shows selected values from reported $\mathrm{P}$ adsorption capacities of different $\mathrm{Mg}$ modified biochar. However, comparisons should proceed with caution as it is difficult to directly compare the values due to variations in experimental conditions. Furthermore, the reported qmax values are based on Langmuir calculated maximum capacity which may entail extrapolating the results beyond the experimental range.

Table 4. Langmuir and Freundlich isotherms parameters for the $\mathrm{PO}_{4}$ adsorption using $\mathrm{Mg}$-biochar.

\begin{tabular}{cccccccc}
\hline & Langmuir Model & & \multicolumn{3}{c}{ Freundlich Model } \\
\hline $\mathbf{q}_{\max }\left(\mathbf{m g ~ P O} \mathbf{P O}_{\mathbf{4}} \mathbf{- P} \cdot \mathbf{g}^{-\mathbf{1}}\right)$ & $\mathbf{K}_{\mathbf{L}}\left(\mathbf{L} \cdot \mathbf{g}^{-1}\right)$ & $\mathbf{R}^{\mathbf{2}}$ & $\mathbf{R M S E}$ & $\mathbf{K}_{\mathbf{F}}$ & $\mathbf{n}$ & $\mathbf{R}^{\mathbf{2}}$ & $\mathbf{R M S E}^{-6}$ \\
\hline 463.5 & $3.65 \times 10^{-5}$ & 0.78 & 0.17 & $6.05 \times 10^{-6}$ & 0.31 & 0.89 & 0.12 \\
\hline
\end{tabular}


Table 5. Adsorption capacities of $\mathrm{PO}_{4}$ by other biochar modified with $\mathrm{Mg}$.

\begin{tabular}{|c|c|c|c|c|}
\hline Biochar Feedstock & $\begin{array}{l}\text { Pyrolysis Temperature } \\
{ }^{\circ} \text { C/Residence Time }\end{array}$ & $\begin{array}{c}\mathrm{C}_{0} \text { of Phosphate } \\
\mathrm{mg} \cdot \mathrm{L}^{-1}\end{array}$ & $\mathrm{q}_{\max }\left(\mathrm{mg} \mathrm{PO}_{4}-\mathrm{P} \cdot \mathrm{g}^{-1}\right)$ & References \\
\hline Longleaf Pine & $500 / 30 \mathrm{~min}$ & 10 to 600 & 4.97 & [45] \\
\hline Red Oak & $500 / 30 \mathrm{~min}$ & 10 to 600 & 6.72 & [45] \\
\hline Poplar chips & $600 / 2 \mathrm{~h}$ & 100 to 500 & 28.94 & [25] \\
\hline Sugarcane crop & $550 / 1 \mathrm{~h}$ & 1 to 500 & 129.49 & [53] \\
\hline Hardwood & $550 / 1.5 \mathrm{~h}$ & 5 to 30 & 463.5 & This study \\
\hline
\end{tabular}

0.7

(a)

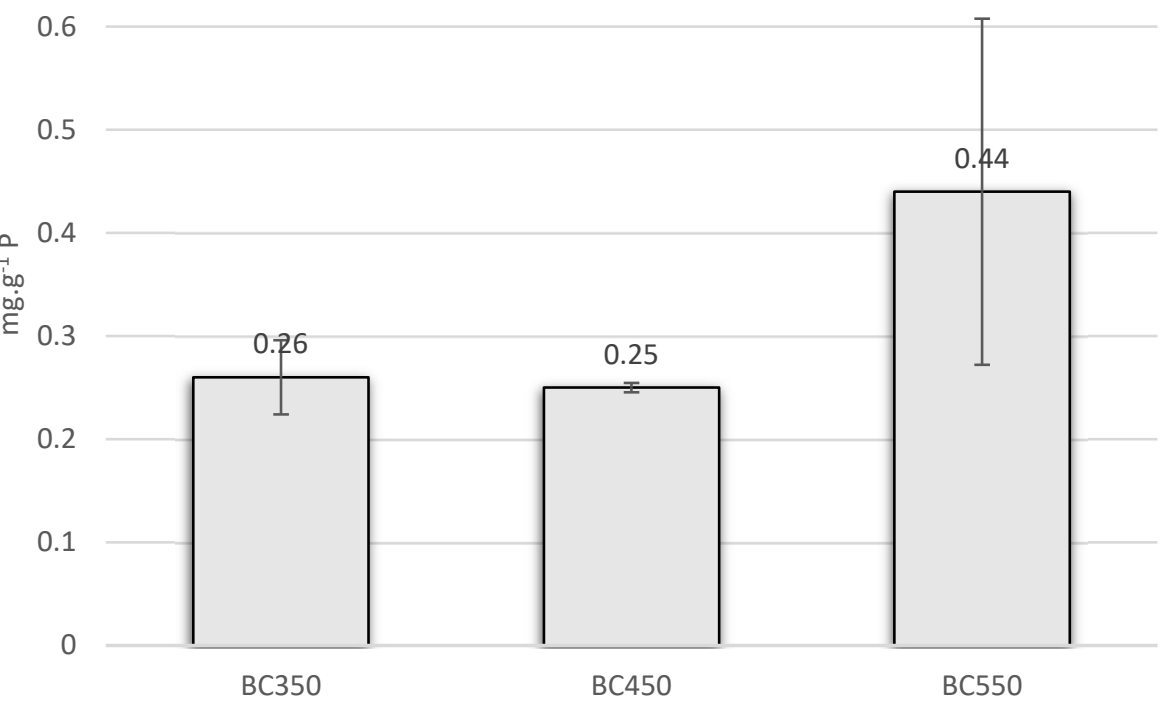

0.8

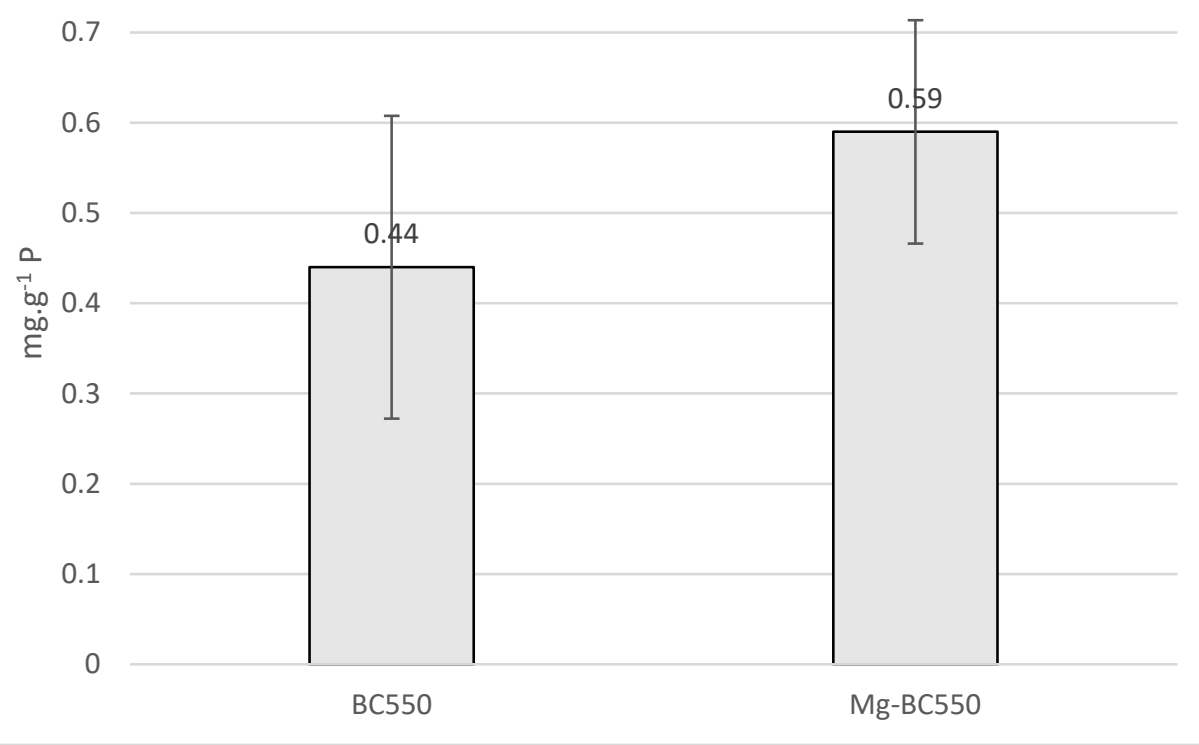

Figure 5. Adsorption of $\mathrm{P}$ by: (a) unmodified biochar at different pyrolysis temperatures; and (b) unmodified and $\mathrm{Mg}$ modified biochar at $550{ }^{\circ} \mathrm{C}$ (mean \pm standard deviation). 

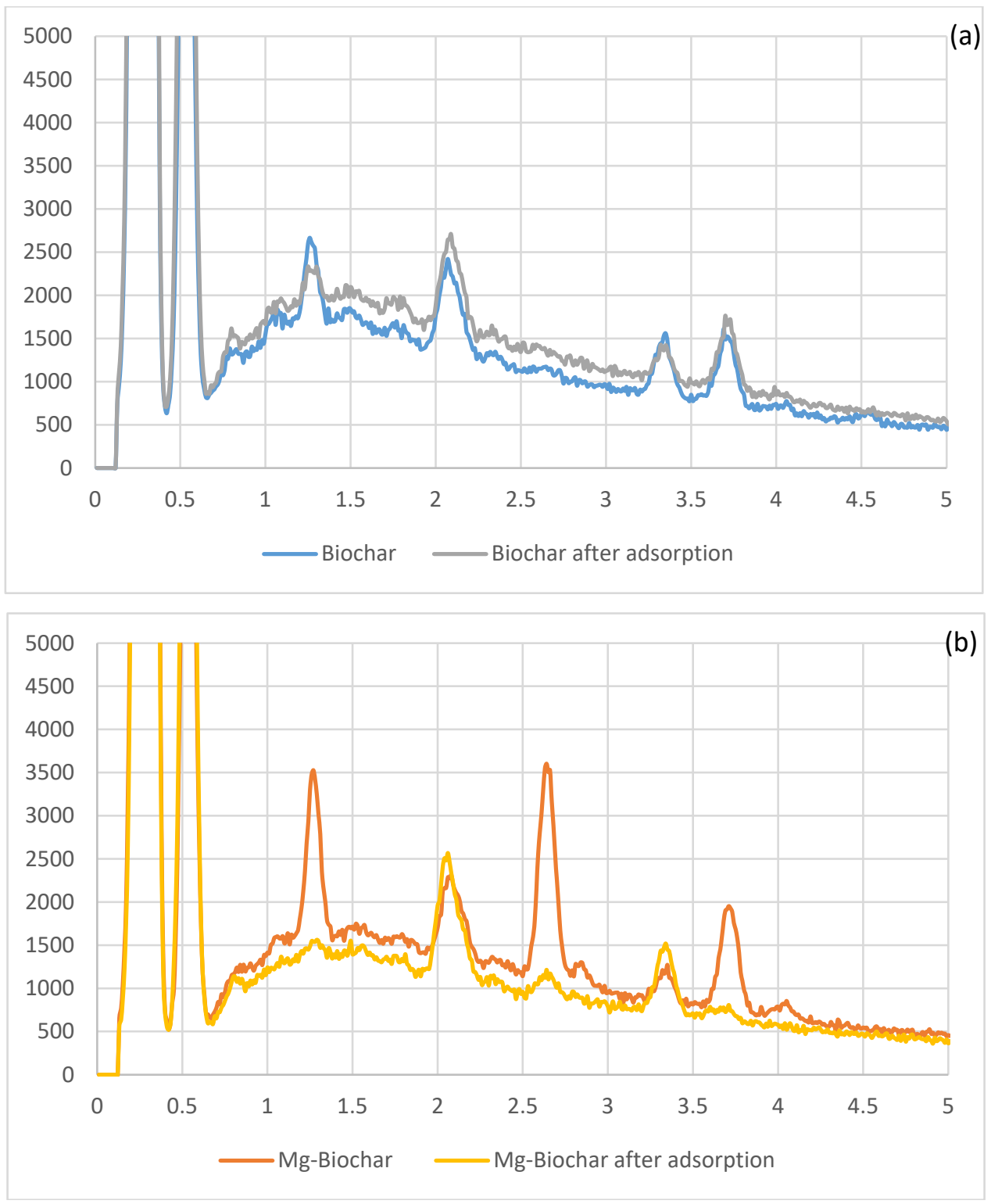

Figure 6. EDS scans before and after adsorption: (a) unmodified biochar; and (b) modified biochar.

\subsection{Adsorption Kinetics}

The adsorption of phosphate by $\mathrm{Mg}$-biochar as a function of time is presented in Figure 8. It is clear that adsorption of $\mathrm{PO}_{4}{ }^{3-}$ at the initial time is fast and then becomes relatively slow. Maximum adsorption was reached in $60 \mathrm{~min}$. The fast initial adsorption of $\mathrm{PO}_{4}{ }^{3-}$ can be caused by electrostatic forces between the positively charged $\mathrm{Mg}$ surface and the slow adsorption later might be due to intraparticle diffusion $[5,53,56]$. The data from the kinetic experiment were further fitted using the pseudo-first- (PFO) and pseudosecond-order (PSO) kinetic models. The pseudo-first- and the pseudo-second-order models fitted the experimental data with correlation coefficients $\mathrm{R}^{2}=0.71$ and 0.73 , respectively. The fitted parameters are shown in Table 6. The PSO model assumes the mechanism of $\mathrm{P}$ adsorption onto $\mathrm{Mg}$-biochar can be determined by chemisorption interaction, which agrees with the isotherm results $[5,53]$. 


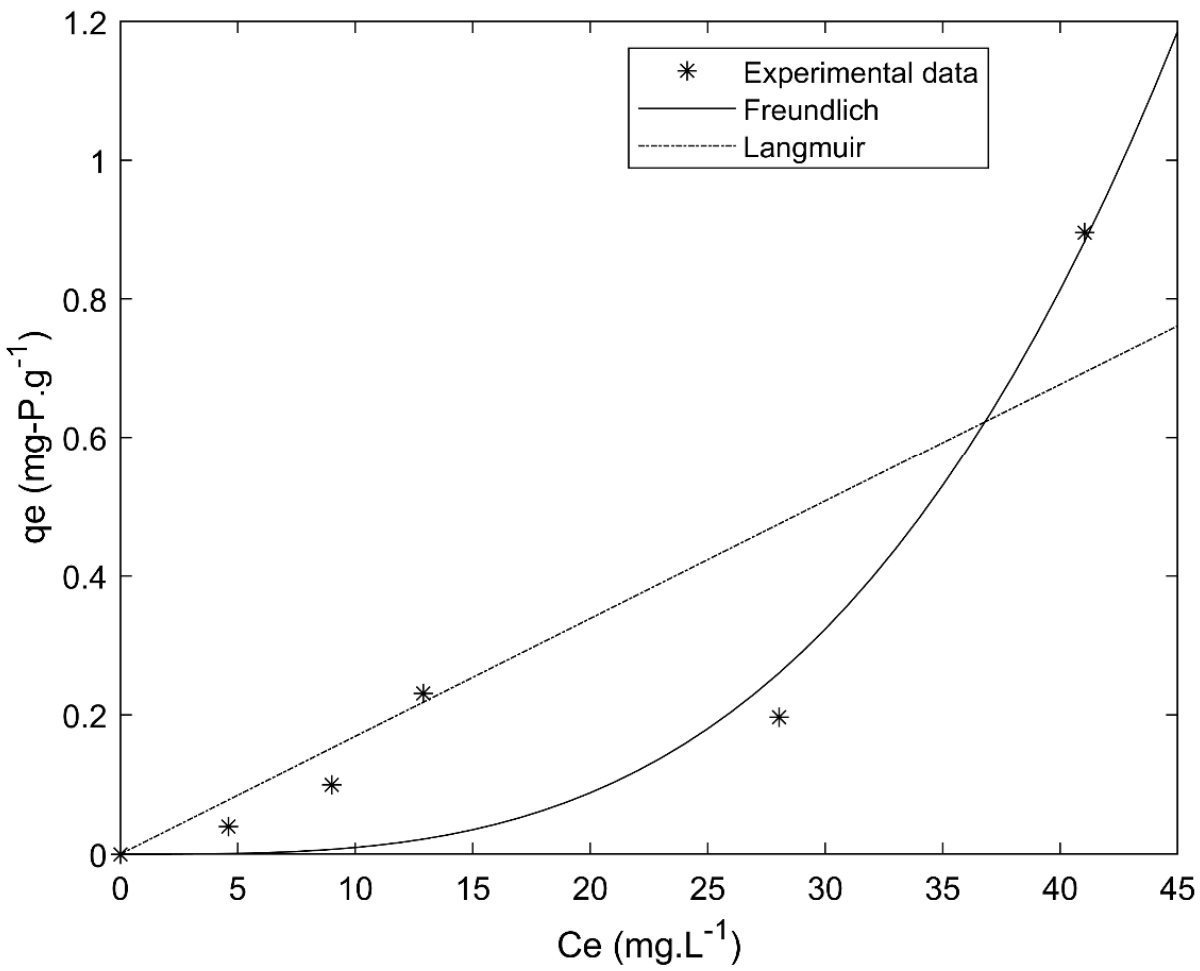

Figure 7. Phosphate adsorption isotherms of Mg-biochar derived from pyrolysis of hardwood.

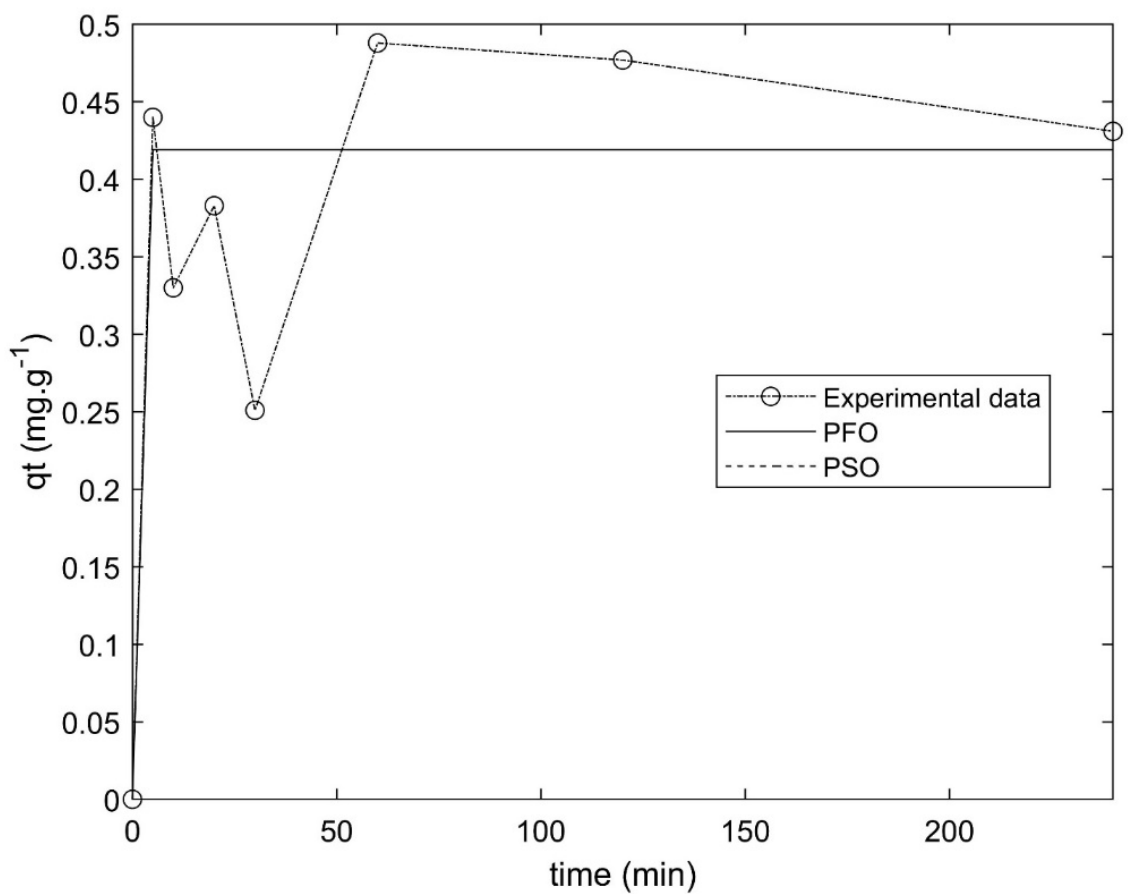

Figure 8. Adsorption kinetics data and modelling for P adsorption on the Mg-biochar.

Table 6. Kinetics models fitting parameters.

\begin{tabular}{ccc}
\hline Parameter & PFO & PSO \\
\hline $\mathrm{k}$ & 4.75 & 1.819 \\
$\mathrm{qe}$ & 0.4192 & 0.4436 \\
$\mathrm{R}^{2}$ & 0.71 & 0.73 \\
RMSE & 0.095 & 0.092 \\
\hline
\end{tabular}


The kinetics data indicate a degree of overshooting behaviour with $\mathrm{q}_{t}$ oscillating as time progresses. One possibility to explain this phenomenon is that, as the biochar has more active positive surface due to the addition of $\mathrm{Mg}, \mathrm{P}$ is attached to this surface; however, the bonding seems to be weak. When the surface of biochar reaches the critical charge density, the new surface charge of biochar is negative because of the phosphate, therefore it starts repelling the incoming phosphate (Figure 9), which looks like there is a release instead of adsorption until equilibrium is reached.

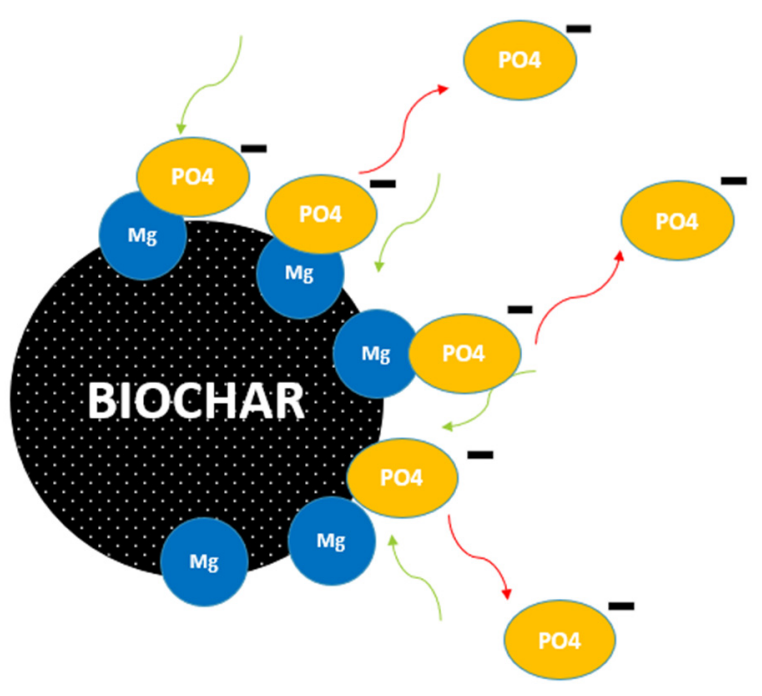

Figure 9. Overshooting phenomena of Mg-biochar.

\subsection{Desorption of $P$ from $M g$-Biochar}

The phosphate release was found to be higher in acidic than in neutral environments, as shown in Figure 10. This is expected, given the dissociation of magnesium and calcium phosphate behaviours. The initial loading of the biochar did not have significant impact on the rate or quantity of the phosphate released. In the case of acidic environment, within the first $5 \mathrm{~min}$ the phosphate concentration released reached $10.6 \mathrm{mg} \mathrm{PO}_{4}-\mathrm{P} \cdot \mathrm{L}^{-1}$ and then remained relatively constant, most likely due to reaching equilibrium between the liquid-solid phase. This demonstrates that Mg-biochar can be used as a carrier to deliver phosphate, but it may not be suitable as a slow-release medium in acidic soils. On the other hand, in neutral environment, the rate of phosphate release was much slower $(\sim 5.5 \%)$ in $24 \mathrm{~h}$ with the curve showing the release continue to climb over time. This percentage is higher than the values reported by Fang and Zhang [24] for Mg biochar derived from corn with release values of $4.4 \%$ over a period of $90 \mathrm{~h}$. This suggests that $\mathrm{Mg}$-biochar may be a good carrier for slow delivery of phosphate in neutral soils.

Judging by the $\mathrm{R}^{2}$ and RMSE values shown in Table 7 , the release of the phosphate followed the bi-phasic desorption model with the fast release component being more prominent in the acidic environment mainly due to the solubilisation of magnesium phosphate. In the case of the neutral environment $(\mathrm{pH}=7)$, only a small fraction of the adsorbed phosphate is immediately available, while the majority of the adsorbed phosphate is being held in the slow-release component. This can be very useful if the biochar is to be used as a carrier for the delivery of phosphate in agricultural applications as the fast release component can provide the phosphate during plant establishment while the slow-release component can ensure steady supply over extended periods of time. 


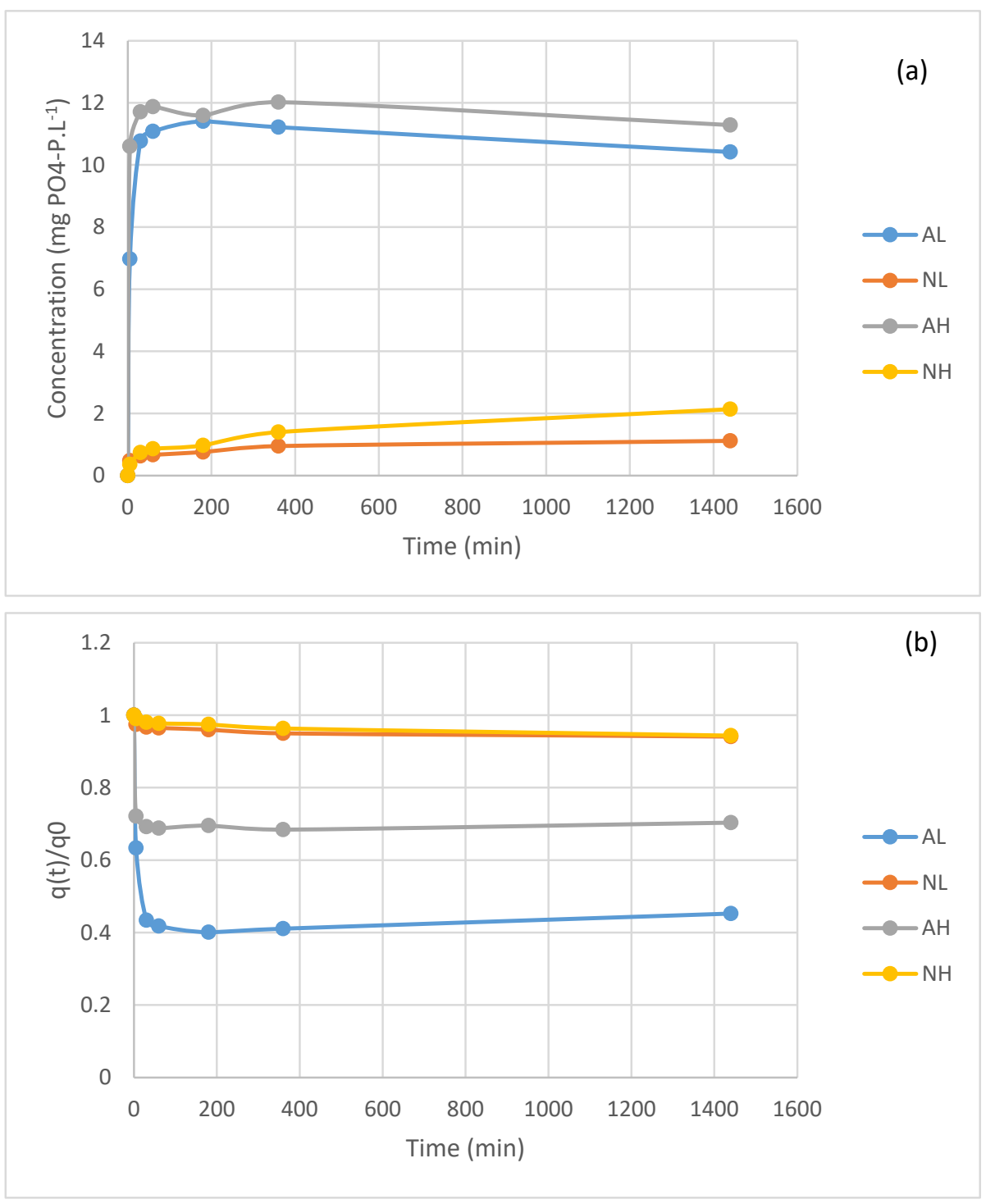

Figure 10. Phosphate release overtime ( $\mathrm{AL}: \mathrm{pH}=4.6$, initial loading $=1.904 \mathrm{mg} \cdot \mathrm{g}^{-1} ; \mathrm{AH}: \mathrm{pH}=4.6$, initial loading $=3.875 \mathrm{mg} \cdot \mathrm{g}^{-1} ; \mathrm{NL}: \mathrm{pH}=7$, initial loading $=1.904 \mathrm{mg} \cdot \mathrm{g}^{-1}$ and $\mathrm{NH}: \mathrm{pH}=7$, initial Loading $=3.875 \mathrm{mg} \cdot \mathrm{g}^{-1}$ ): (a) Phosphate concentration in the solution; (b) Phosphate release from solid phase.

Table 7. Desorption two term exponential model fitting parameters.

\begin{tabular}{|c|c|c|c|c|c|}
\hline \multicolumn{6}{|c|}{ FRD } \\
\hline Desorption Environment & $\mathrm{q}_{0}$ & $\mathbf{k}$ & $\mathbf{R}^{2}$ & RMSE & \\
\hline $\mathrm{AL}$ & 1.104 & $3.048 \times 10^{-4}$ & 0.09628 & 0.4358 & \\
\hline $\mathrm{AH}$ & 2.884 & $7.731 \times 10^{-5}$ & 0.06052 & 0.4648 & \\
\hline NL & 1.853 & $2.678 \times 10^{-5}$ & 0.494 & 0.3928 & \\
\hline $\mathrm{NH}$ & 3.751 & $3.234 \times 10^{-5}$ & 0.7788 & 0.03592 & \\
\hline \multicolumn{6}{|c|}{ TFRC } \\
\hline Desorption Environment & a & $\mathbf{k}_{\mathrm{f}}$ & $\mathbf{k}_{\mathrm{s}}$ & $\mathbf{R}^{2}$ & RMSE \\
\hline $\mathrm{AL}$ & 0.5754 & -0.2017 & $-1.342 \times 10^{-4}$ & 0.9988 & 0.01293 \\
\hline $\mathrm{AH}$ & 0.3072 & -0.4727 & $-2.49 \times 10^{-5}$ & 0.9993 & 0.005097 \\
\hline NL & 0.03642 & -0.2318 & $-1.761 \times 10^{-5}$ & 0.9277 & 0.005075 \\
\hline $\mathrm{NH}$ & 0.02195 & -0.05333 & $-2.415 \times 10^{-5}$ & 0.9801 & 0.003657 \\
\hline
\end{tabular}




\section{Conclusions}

Impregnation of biochar with $\mathrm{Mg}$ enhanced the phosphate adsorption capacity of the biochar by $34 \%$. Formation of magnesium phosphate is the likely cause for the observed increase in capacity. The adsorption isotherm was best described by the Freundlich isotherm model and the kinetics were best described by the pseudo-second-order equation, suggesting that multiple mechanisms were involved in the adsorption of phosphate. Desorption experiments revealed that the desorption behaviour of the phosphate from biochar follows bi-phasic exponential decay model with fast- and slow-release components. The $\mathrm{pH}$ plays an important role in determining the distribution of the phosphate between the fast- and slow-release components. This behaviour is very useful if the exhausted biochar were to be used as a carrier for phosphate delivery in agricultural settings. The fast release component can provide the phosphate dose required during plant establishment while the slow-release component ensures the steady supply of phosphate over extended periods of time.

Author Contributions: Conceptualisation, A.E.H.; methodology, A.E.H.; software, L.A.B. and A.E.H.; validation, A.E.H.; formal analysis, L.A.B. and A.E.H.; investigation, L.A.B. and Z.M.; resources, A.E.H. and C.P.; data curation, L.A.B.; writing—original draft preparation, L.A.B.; writing-review and editing, A.E.H., Z.M. and C.P.; visualisation, L.A.B. and A.E.H.; supervision, A.E.H.; project administration, A.E.H. and C.P.; and funding acquisition, C.P. and A.E.H. All authors have read and agreed to the published version of the manuscript.

Funding: This research was funded by Griffith University's School of Environment and Science ENGAGE Initiative.

Institutional Review Board Statement: No human or animal subjects were involved in this study. Note applicable.

Informed Consent Statement: Not applicable.

Data Availability Statement: Data are contained within the article.

Conflicts of Interest: The authors declare no conflict of interest.

\section{References}

1. Takaya, C.; Fletcher, L.; Singh, S.; Anyikude, K.; Ross, A. Phosphate and ammonium sorption capacity of biochar and hydrochar from different wastes. Chemosphere 2016, 145, 518-527. [CrossRef] [PubMed]

2. Qian, T.; Zhang, X.; Hu, J.; Jiang, H. Effects of environmental conditions on the release of phosphorus from biochar. Chemosphere 2013, 93, 2069-2075. [CrossRef]

3. Jung, K.-W.; Lee, S.; Lee, Y.J. Synthesis of novel magnesium ferrite (MgFe2O4)/biochar magnetic composites and its adsorption behavior for phosphate in aqueous solutions. Bioresour. Technol. 2017, 245, 751-759. [CrossRef]

4. Xu, K.; Zhang, C.; Dou, X.; Ma, W.; Wang, C. Optimizing the modification of wood waste biochar via metal oxides to remove and recover phosphate from human urine. Environ. Geochem. Health 2019, 41, 1767-1776. [CrossRef]

5. Wu, L.; Wei, C.; Zhang, S.; Wang, Y.; Kuzyakov, Y.; Ding, X. MgO-modified biochar increases phosphate retention and rice yields in saline-alkaline soil. J. Clean. Prod. 2019, 235, 901-909. [CrossRef]

6. Yin, Q.; Wang, R.; Zhao, Z. Application of Mg-Al-modified biochar for simultaneous removal of ammonium, nitrate, and phosphate from eutrophic water. J. Clean. Prod. 2018, 176, 230-240. [CrossRef]

7. Jung, K.-W.; Ahn, K.-H. Fabrication of porosity-enhanced MgO/biochar for removal of phosphate from aqueous solution: Application of a novel combined electrochemical modification method. Bioresour. Technol. 2016, 200, 1029-1032. [CrossRef]

8. Saxena, J.; Rawat, J.; Kumar, R. Conversion of biomass waste into biochar and the effect on Mung bean crop production. Clean Soil Air Water 2017, 45. [CrossRef]

9. Ding, Y.; Liu, Y.; Liu, S.; Huang, X.; Li, Z.; Tan, X.; Zeng, G.; Zhou, L. Potential benefits of biochar in agricultural soils: A review. Pedosphere 2017, 27, 645-661. [CrossRef]

10. Kavitha, B.; Reddy, P.V.L.; Kim, B.; Lee, S.S.; Pandey, S.K.; Kim, K.-H. Benefits and limitations of biochar amendment in agricultural soils: A review. J. Environ. Manag. 2018, 227, 146-154. [CrossRef] [PubMed]

11. Morales, M.M.; Comerford, N.; Guerrini, I.A.; Falcão, N.P.S.; Reeves, J.B. Sorption and desorption of phosphate on biochar and biochar-soil mixtures. Soil Use Manag. 2013, 29, 306-314. [CrossRef]

12. Amin, F.R.; Huang, Y.; He, Y.; Zhang, R.; Liu, G.; Chen, C. Biochar applications and modern techniques for characterization. Clean Technol. Environ. Policy 2016, 18, 1457-1473. [CrossRef]

13. Ndirangu, S.M.; Liu, Y.; Xu, K.; Song, S. Risk evaluation of pyrolyzed biochar from multiple wastes. J. Chem. 2019, $2019,4506314$. [CrossRef] 
14. Tomczyk, A.; Sokołowska, Z.; Boguta, P. Biochar physicochemical properties: Pyrolysis temperature and feedstock kind effects. Rev. Environ. Sci. Bio/Technol. 2020, 19, 191-215. [CrossRef]

15. Dugdug, A.A.; Chang, S.X.; Ok, Y.S.; Rajapaksha, A.U.; Anyia, A. Phosphorus sorption capacity of biochars varies with biochar type and salinity level. Environ. Sci. Pollut. Res. 2018, 25, 25799-25812. [CrossRef]

16. Mukome, F.N.D.; Zhang, X.; Silva, L.C.R.; Six, J.; Parikh, S.J. Use of chemical and physical characteristics to investigate trends in biochar feedstocks. J. Agric. Food Chem. 2013, 61, 2196-2204. [CrossRef]

17. Man, Y.; Chen, Y. Enhanced phosphate adsorption on Ca-Mg-loaded biochar derived from tobacco stems. Water Sci. Technol. 2018, 78, 2427-2436.

18. Chen, Q.; Qin, J.; Sun, P.; Cheng, Z.; Shen, G. Cow dung-derived engineered biochar for reclaiming phosphate from aqueous solution and its validation as slow-release fertilizer in soil-crop system. J. Clean. Prod. 2018, 172, 2009-2018. [CrossRef]

19. Yang, Q.; Wang, X.; Luo, W.; Sun, J.; Xu, Q.; Chen, F.; Zhao, J.; Wang, S.; Yao, F.; Wang, D.; et al. Effectiveness and mechanisms of phosphate adsorption on iron-modified biochars derived from waste activated sludge. Bioresour. Technol. 2018, 247, 537-544. [CrossRef] [PubMed]

20. Wang, Z.; Guo, H.; Shen, F.; Yang, G.; Zhang, Y.; Zeng, Y.; Wang, L.; Xiao, H.; Deng, S. Biochar produced from oak sawdust by Lanthanum (La)-involved pyrolysis for adsorption of ammonium $\left(\mathrm{NH}^{4+}\right)$, nitrate $\left(\mathrm{NO}^{3-}\right)$, and phosphate $\left(\mathrm{PO}_{4}{ }^{3-}\right)$. Chemosphere 2015, 119, 646-653. [CrossRef]

21. Micháleková-Richveisová, B.; Frišták, V.; Piṕí̌ka, M.; Ďuriška, L.; Moreno-Jimenez, E.; Soja, G. Iron-impregnated biochars as effective phosphate sorption materials. Environ. Sci. Pollut. Res. 2017, 24, 463-475. [CrossRef]

22. Wang, Z.; Shen, D.; Shen, F.; Li, T. Phosphate adsorption on lanthanum loaded biochar. Chemosphere 2016, 150, 1-7. [CrossRef]

23. Kuppusamy, S.; Thavamani, P.; Megharaj, M.; Venkateswarlu, K.; Naidu, R. Agronomic and remedial benefits and risks of applying biochar to soil: Current knowledge and future research directions. Environ. Int. 2016, 87, 1-12. [CrossRef]

24. Fang, C.; Zhang, T.; Li, P.; Jiang, R.-F.; Wang, Y.-C. Application of magnesium modified corn biochar for phosphorus removal and recovery from swine wastewater. Int. J. Environ. Res. Public Health 2014, 11, 9217-9237. [CrossRef]

25. Yin, Q.Q.; Liu, M.T.; Ren, H.P. Removal of ammonium and phosphate from water by Mg-modified biochar: Influence of Mg pretreatment and pyrolysis temperature. Bioresources 2019, 14, 6203-6218.

26. Takaya, C.; Fletcher, L.; Singh, S.; Okwuosa, U.; Ross, A. Recovery of phosphate with chemically modified biochars. J. Environ. Chem. Eng. 2016, 4, 1156-1165. [CrossRef]

27. Wan, S.; Wang, S.; Li, Y.; Gao, B. Functionalizing biochar with Mg-Al and Mg-Fe layered double hydroxides for removal of phosphate from aqueous solutions. J. Ind. Eng. Chem. 2017, 47, 246-253. [CrossRef]

28. Park, J.H.; Ok, Y.S.; Kim, S.H.; Cho, J.S.; Heo, J.S.; Delaune, R.D.; Seo, D.C. Evaluation of phosphorus adsorption capacity of sesame straw biochar on aqueous solution: Influence of activation methods and pyrolysis temperatures. Environ. Geochem. Health 2015, 37, 969-983. [CrossRef]

29. Liao, T.; Li, T.; Su, X.; Yu, X.; Song, H.; Zhu, Y.; Zhang, Y. La(OH)3-modified magnetic pineapple biochar as novel adsorbents for efficient phosphate removal. Bioresour. Technol. 2018, 263, 207-213. [CrossRef] [PubMed]

30. Li, J.; Li, B.; Huang, H.; Zhao, N.; Zhang, M.; Cao, L. Investigation into lanthanum-coated biochar obtained from urban dewatered sewage sludge for enhanced phosphate adsorption. Sci. Total. Environ. 2020, 714, 136839. [CrossRef] [PubMed]

31. Wang, L.; Wang, J.; He, C.; Lyu, W.; Zhang, W.; Yan, W.; Yang, L. Development of rare earth element doped magnetic biochars with enhanced phosphate adsorption performance. Colloids Surf. A Physicochem. Eng. Asp. 2019, 561, 236-243. [CrossRef]

32. Yang, B.; Feng, Y.; Yu, Y.; He, S.; Liu, H.; Xue, L.; Yang, L. Lanthanum ferrite nanoparticles modification onto biochar: Derivation from four different methods and high performance for phosphate adsorption. Environ. Sci. Pollut. Res. 2019, 26, 22010-22020. [CrossRef] [PubMed]

33. Nguyen, T.A.; Ngo, H.H.; Guo, W.S.; Zhang, J.; Liang, S.; Tung, K.L. Feasibility of iron loaded 'okara' for biosorption of phosphorous in aqueous solutions. Bioresour. Technol. 2013, 150, 42-49. [CrossRef]

34. Li, Z.; Liu, X.; Wang, Y. Modification of sludge-based biochar and its application to phosphorus adsorption from aqueous solution. J. Mater. Cycles Waste Manag. 2019, 22, 123-132. [CrossRef]

35. Ren, J.; Li, N.; Li, L.; An, J.-K.; Zhao, L.; Ren, N.-Q. Granulation and ferric oxides loading enable biochar derived from cotton stalk to remove phosphate from water. Bioresour. Technol. 2015, 178, 119-125. [CrossRef] [PubMed]

36. Novais, S.V.; Zenero, M.D.O.; Barreto, M.S.C.; Montes, C.R.; Cerri, C.E.P. Phosphorus removal from eutrophic water using modified biochar. Sci. Total. Environ. 2018, 633, 825-835. [CrossRef] [PubMed]

37. Akgül, G.; Maden, T.B.; Diaz, E.; Jiménez, E.M. Modification of tea biochar with $\mathrm{Mg}$, Fe, $\mathrm{Mn}$ and Al salts for efficient sorption of PO43- and Cd2+ from aqueous solutions. J. Water Reuse Desalination 2019, 9, 57-66. [CrossRef]

38. Hale, S.E.; Alling, V.; Martinsen, V.; Mulder, J.; Breedveld, G.D.; Cornelissen, G. The sorption and desorption of phosphate-P, ammonium-N and nitrate-N in cacao shell and corn cob biochars. Chemosphere 2013, 91, 1612-1619. [CrossRef]

39. Mahdi, Z.; El Hanandeh, A.; Yu, Q. Influence of pyrolysis conditions on surface characteristics and methylene blue adsorption of biochar derived from date seed biomass. Waste Biomass Valorization 2016, 8, 2061-2073. [CrossRef]

40. Birdwell, J.; Cook, R.L.; Thibodeaux, L.J. Desorption kinetics of hydrophobic organic chemicals from sediment to water: A review of data and models. Environ. Toxicol. Chem. 2007, 26, 424-434. [CrossRef]

41. Chen, X.; Chen, G.; Chen, L.; Chen, Y.; Lehmann, J.; McBride, M.B.; Hay, A.G. Adsorption of copper and zinc by biochars produced from pyrolysis of hardwood and corn straw in aqueous solution. Bioresour. Technol. 2011, 102, 8877-8884. [CrossRef] 
42. Domingues, R.R.; Trugilho, P.F.; Silva, C.A.; De Melo, I.C.N.A.; Melo, L.C.A.; Magriotis, Z.M.; Sánchez-Monedero, M.A. Properties of biochar derived from wood and high-nutrient biomasses with the aim of agronomic and environmental benefits. PLoS ONE 2017, 12, e0176884. [CrossRef]

43. Ola, F.; Jekayinfa, S. Pyrolysis of sandbox (Hura crepitans) shell: Effect of pyrolysis parameters on biochar yield. Res. Agric. Eng. 2016, 61, 170-176. [CrossRef]

44. Tag, A.T.; Duman, G.; Ucar, S.; Yanik, J. Effects of feedstock type and pyrolysis temperature on potential applications of biochar. J. Anal. Appl. Pyrolysis 2016, 120, 200-206. [CrossRef]

45. Oginni, O.; Yakaboylu, G.A.; Singh, K.; Sabolsky, E.M.; Unal-Tosun, G.; Jaisi, D.; Khanal, S.; Shah, A. Phosphorus adsorption behaviors of $\mathrm{MgO}$ modified biochars derived from waste woody biomass resources. J. Environ. Chem. Eng. 2020, 8. [CrossRef]

46. Lu, S.; Zong, Y. Pore structure and environmental serves of biochars derived from different feedstocks and pyrolysis conditions. Environ. Sci. Pollut. Res. 2018, 25, 30401-30409. [CrossRef] [PubMed]

47. Li, H.; Dong, X.; da Silva, E.B.; de Oliveira, L.M.; Chen, Y.; Ma, L.Q. Mechanisms of metal sorption by biochars: Biochar characteristics and modifications. Chemosphere 2017, 178, 466-478. [CrossRef] [PubMed]

48. Zhang, H.; Chen, C.; Gray, E.M.; Boyd, S.E. Effect of feedstock and pyrolysis temperature on properties of biochar governing end use efficacy. Biomass Bioenergy 2017, 105, 136-146. [CrossRef]

49. Cui, X.; Dai, X.; Khan, K.Y.; Li, T.; Yang, X.; He, Z. Removal of phosphate from aqueous solution using magnesiumalginate/chitosan modified biochar microspheres derived from Thalia dealbata. Bioresour. Technol. 2016, 218, 1123-1132. [CrossRef]

50. Coates, J. Interpretation of infrared spectra, A practical approach. In Encyclopedia of Analytical Chemistry: Applications, Theory and Instrumentation; John Wiley \& Sons Ltd.: Chichester, UK, 2000; pp. 10815-10837.

51. Jung, K.-W.; Kim, K.; Jeong, T.-U.; Ahn, K.-H. Influence of pyrolysis temperature on characteristics and phosphate adsorption capability of biochar derived from waste-marine macroalgae (Undaria pinnatifida roots). Bioresour. Technol. 2016, 200, 1024-1028. [CrossRef] [PubMed]

52. Zhou, L.; Xu, D.; Li, Y.; Pan, Q.; Wang, J.; Xue, L.; Howard, A. Phosphorus and nitrogen adsorption capacities of biochars derived from feedstocks at different pyrolysis temperatures. Water 2019, 11, 1559. [CrossRef]

53. Li, R.; Wang, J.J.; Zhou, B.; Zhang, Z.; Liu, S.; Lei, S.; Xiao, R. Simultaneous capture removal of phosphate, ammonium and organic substances by $\mathrm{MgO}$ impregnated biochar and its potential use in swine wastewater treatment. J. Clean. Prod. 2017, 147, 96-107. [CrossRef]

54. Marshall, J.A.; Morton, B.J.; Muhlack, R.; Chittleborough, D.; Kwong, C.W. Recovery of phosphate from calcium-containing aqueous solution resulting from biochar-induced calcium phosphate precipitation. J. Clean. Prod. 2017, 165, 27-35. [CrossRef]

55. Foo, K.; Hameed, B. Insights into the modeling of adsorption isotherm systems. Chem. Eng. J. 2010, 156, 2-10. [CrossRef]

56. Huang, H.; Zhang, P.; Zhang, Z.; Liu, J.; Xiao, J.; Gao, F. Simultaneous removal of ammonia nitrogen and recovery of phosphate from swine wastewater by struvite electrochemical precipitation and recycling technology. J. Clean. Prod. 2016, 127, 302-310. [CrossRef] 